\title{
Preliminary Volcano-Hazard Assessment for the Emmons Lake Volcanic Center, Alaska
}

Scientific Investigations Report 2006-5248

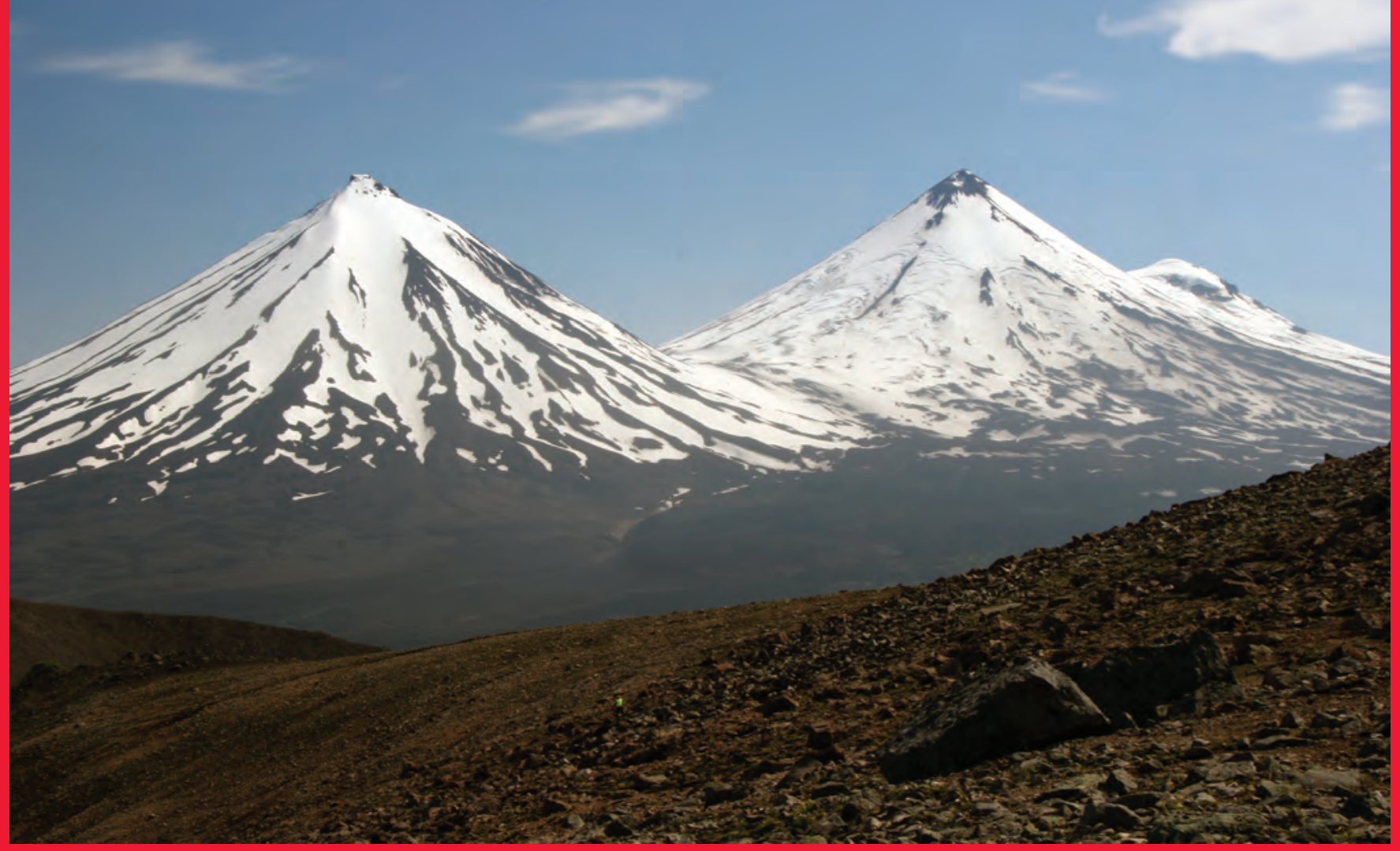

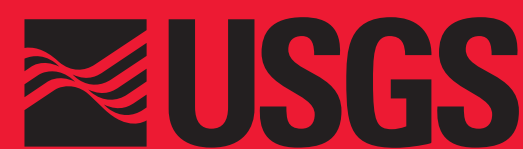

science for a changing world
This report is preliminary and subject to revision as new data become available

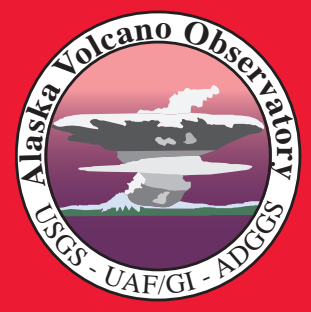


The Alaska Volcano Observatory (AVO) was established in 1988 to monitor dangerous volcanoes, issue eruption alerts, assess volcano hazards, and conduct volcano research in Alaska. The cooperating agencies of AVO are the U.S. Geological Survey (USGS), the University of Alaska Fairbanks Geophysical Institute (UAFGI), and the Alaska Division of Geological and Geophysical Surveys (ADGGS). AVO also plays a key role in notification and tracking eruptions on the Kamchatka Peninsula of the Russian Far East as part of a formal working relationship with the Kamchatkan Volcanic eruptions Response Team.

Cover Photograph. View of major stratocones in the eastern part of the Emmons Lake volcanic center. From left to right, Pavlof Sister, Pavlof, and Little Pavlof, view is to the southwest from Trader Mountain. Pavlof volcano is the most historically active volcano in Alaska and last erupted in 1996, Pavlof Sister and Little Pavlof have had no known historical eruptions, but were likely active over the past 10,000 years. Photograph by C.F. Waythomas, August, 2005. 


\section{Preliminary Volcano Hazard Assessment for the Emmons Lake Volcanic Center, Alaska}

By Christopher F. Waythomas, Thomas P. Miller, and Margaret T. Mangan

Scientific Investigations Report 2006-5248 


\section{U.S. Department of the Interior DIRK KEMPTHORNE, Secretary \\ U.S. Geological Survey \\ P. Patrick Leahy, Acting Director}

\section{U.S. Geological Survey, Reston, Virginia: 2006}

For product and ordering information:

World Wide Web: http://www.usgs.gov/pubprod

Telephone: 1-888-ASK-USGS

For more information on the USGS--the Federal source for science about the Earth, its natural and living resources, natural hazards, and the environment:

World Wide Web: http://www.usgs.gov

Telephone: 1-888-ASK-USGS

Any use of trade, product, or firm names is for descriptive purposes only and does not imply endorsement by the U.S. Government.

Although this report is in the public domain, permission must be secured from the individual copyright owners to reproduce any copyrighted materials contained within this report.

Suggested citation:

Waythomas, C.F., Miller, T.P., and Mangan, M.T., 2006, Preliminary Volcano Hazard Assessment for the Emmons Lake Volcanic Center, Alaska: Anchorage, Alaska, U.S. Geological Survey, Scientific Investigations Report 2006-5248. 


\section{Contents}

Summary of Hazards at the Emmons Lake Volcanic Center...........................................................

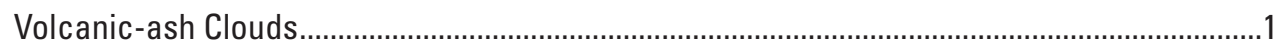

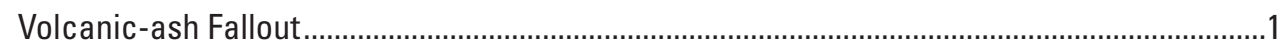

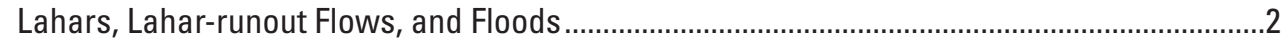

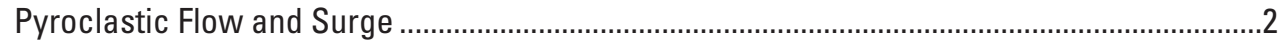

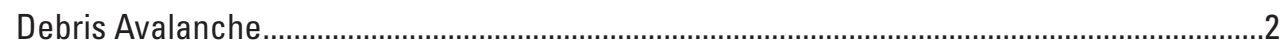

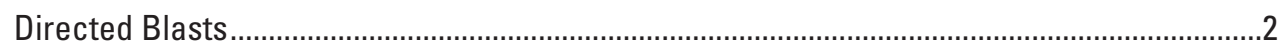

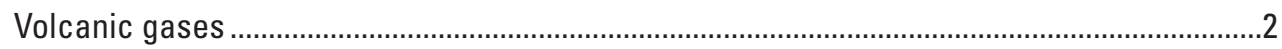

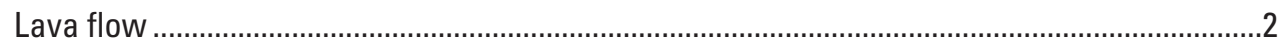

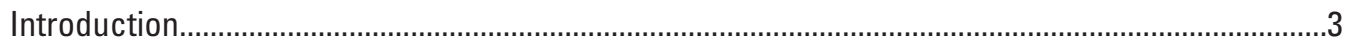

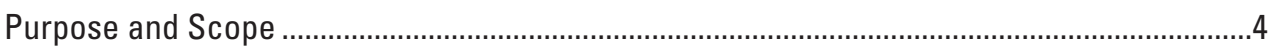

Physical Setting of the Emmons Lake Volcanic Center .............................................................

Prehistoric Eruptive Activity ............................................................................................................

Historical Eruptive Activity .............................................................................................................

Hazardous Phenomena Associated with Eruptions........................................................................11

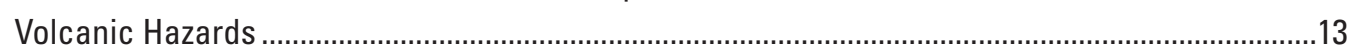

Volcanic-ash Clouds .........................................................................................................

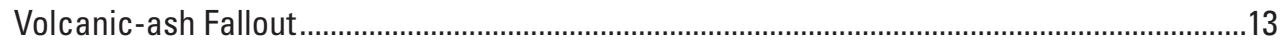

Lahars, Lahar-Runout Flows, and Floods ............................................................................15

Debris Avalanche

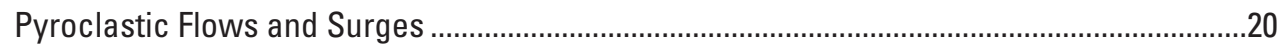

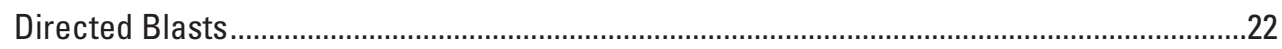

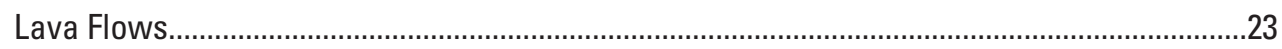

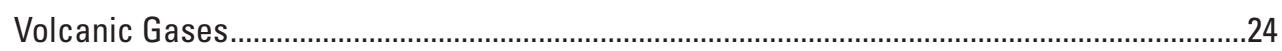

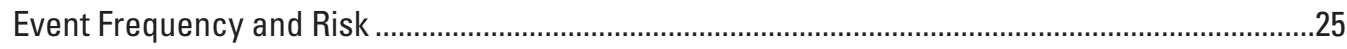

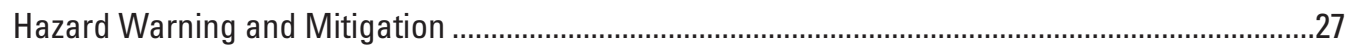

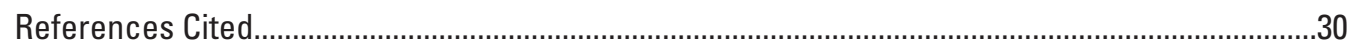

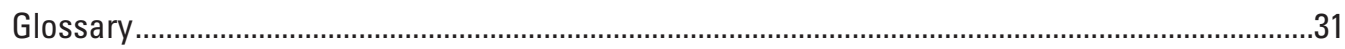

\section{Figures}

1. Location of the Emmons Lake volcanic center on the Alaska Peninsula of southwestern

Alaska and major stratocones in the region ....................................................................

2. Major volcanic features, structures, and stratocones within the Emmons Lake volcanic

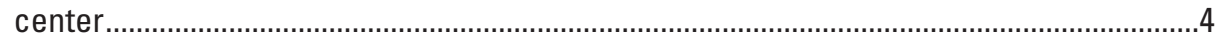

3. Photograph of Mt. Emmons and Emmons Lake. View is to the north........................................5

4a. Photograph of Mount Hague, an unnamed stratocone northwest of Hague (1), and location of fumaroles (2) on southeast flank. View is to the northeast ..............................................

4b. Photograph of southern crater of Mount Hague showing steaming ephemeral lake .................5 
5. Photograph of Double Crater, Little Pavlof, Pavlof, and Pavlof Sister volcanoes ......................6

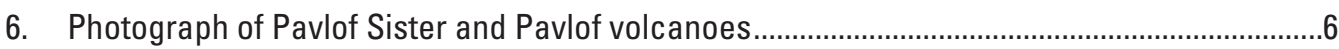

7. Summary of the major volcanic events at the Emmons Lake volcanic center as determined by recent geologic and geochronologic studies .................................................................

8. Simplified geologic map of the Emmons Lake volcanic center ................................................8

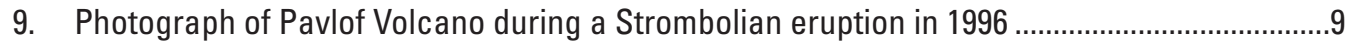

10. Photograph of summit area of Pavlof Volcano, showing 1996 vent, areas of spatter accumulation, and 1996 lahar deposit. View is to the southeast.....................................10

11. Schematic diagram showing volcanic processes and hazards at stratovolcanoes................11

12. Map showing extent of tephra fallout from historical eruptions of Pavlof Volcano.................15

13a. Prevailing-wind directions for southwestern and south-central Alaska ................................16

13b. Areas most likely to receive ash fallout from eruptions of the Emmons Lake volcanic center. The specific area of tephra fallout will depend on wind direction and speed ...16

14. Areas likely to be inundated by lahars, lahar runout flows, and floods ..................................17

15. Photograph of lahar deposits produced by historical eruptions of Pavlof Volcano ..................18

16. Photograph of the north flank of Pavlof Sister volcano showing possible debris-avalanche scars

17. Extent of debris-avalanche hazard zone for Pavlof Volcano.................................................19

18. Extent of debris-avalanche hazard zone for Pavlof Sister, Little Pavlof, Hague, and Mount Emmons volcanoes................................................................................................20

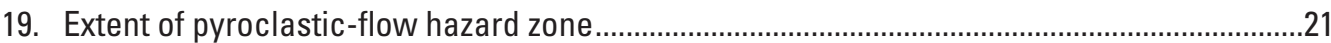

20. Photograph of pumice-rich, pyroclastic flow deposits exposed along the Bering Sea coast north of the Emmons Lake volcanic center ..........................................................22

21. Extent of directed blast hazard zone ..................................................................................2

22. Photograph of lava flows of Holocene age erupted from Cone $A$ and terminating in

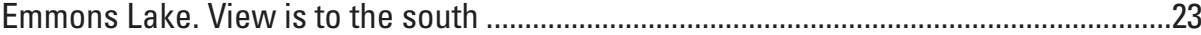

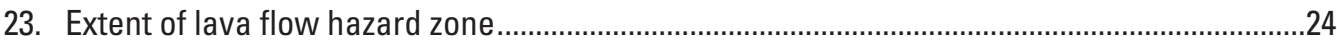

24. Map showing location of hot springs, fumaroles, and acidic lakes and potential sites for volcanic gas emission

25. Map showing principal air routes over the North Pacific Ocean relative to the Emmons Lake volcanic center and other volcanoes in Alaska, Russia, the Kurile Islands, and Japan

\section{Tables}

1. Outline of Historical Eruptive Activity for Pavlof Volcano ........................................................12

2. Major hazards from eruptions of the Emmons Lake volcanic center......................................14

3. Probability of eruptive activity for main vents in the Emmons Lake volcanic center ...............26

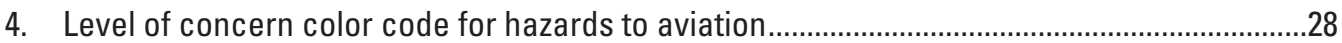

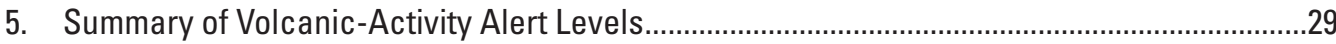




\section{Conversion Factors, Datums, and Acronyms}

\begin{tabular}{lcl}
\hline Multiply & By & To obtain \\
\hline millimeter $(\mathrm{mm})$ & Length & \\
centimeter $(\mathrm{cm})$ & 0.03937 & inch \\
meter $(\mathrm{m})$ & 0.3937 & inch \\
\hline kilometer $(\mathrm{km})$ & 3.281 & foot \\
\hline & 0.6214 & mile \\
\hline square meter $\left(\mathrm{m}^{2}\right)$ & Area & square foot \\
cubic meter $\left(\mathrm{m}^{3}\right)$ & 10.76 & cubic mile \\
cubic kilometer $\left.(\mathrm{km})^{3}\right)$ & 35.31 & cubic mile \\
\hline & 0.2399 & \\
\hline meter per second $(\mathrm{m} / \mathrm{s})$ & Flow rate & foot per second \\
meter per hour $(\mathrm{m} / \mathrm{h})$ & 3.281 & feet per hour \\
\hline cubic meter per second $\left(\mathrm{m}^{3} / \mathrm{s}\right)$ & 3.281 & cubic foot per second \\
\hline meter per square second $\left(\mathrm{m} / \mathrm{s}^{2}\right)$ & 35.31 & foot per square second \\
\hline
\end{tabular}

Temperature in degrees Celsius $\left({ }^{\circ} \mathrm{C}\right)$ may be converted to degrees Fahrenheit $\left({ }^{\circ} \mathrm{F}\right)$ as follows:

$$
{ }^{\circ} \mathrm{F}=\left(1.8 x^{\circ} \mathrm{C}\right)+32 .
$$

Sea level: In this report, "sea level" refers to the National Geodetic Vertical Datum of 1929 (NGVD of 1929, formerly called "Sea-Level Datum of 1929"), which is derived from a general adjustment of the first-order leveling networks of the United States and Canada. In the area of this report, datum is mean lower low water. 
This page is intentionally left blank 


\title{
Preliminary Volcano Hazard Assessment for the Emmons Lake Volcanic Center, Alaska
}

\author{
By Christopher F. Waythomas, Thomas P. Miller, and Margaret T. Mangan
}

\section{Summary of Hazards at the Emmons Lake Volcanic Center}

The Emmons Lake volcanic center is a large stratovolcano complex on the Alaska Peninsula near Cold Bay, Alaska. The volcanic center includes several ice- and snow-clad volcanoes within a nested caldera structure that hosts Emmons Lake and truncates a shield-like ancestral Mount Emmons edifice. From northeast to southwest, the main stratovolcanoes of the center are: Pavlof Sister, Pavlof, Little Pavlof, Double Crater, Mount Hague, and Mount Emmons. Several small cinder cones and vents are located on the floor of the caldera and on the south flank of Pavlof Volcano. Pavlof Volcano, in the northeastern part of the center, is the most historically active volcano in Alaska (Miller and others, 1998) and eruptions of Pavlof pose the greatest hazards to the region.

Historical eruptions of Pavlof Volcano have been small to moderate Strombolian eruptions that produced moderate amounts of near vent lapilli tephra fallout, and diffuse ash plumes that drifted several hundreds of kilometers from the vent. Cold Bay, King Cove, Nelson Lagoon, and Sand Point have reported ash fallout from Pavlof eruptions. Drifting clouds of volcanic ash produced by eruptions of Pavlof would be a major hazard to local aircraft and could interfere with trans-Pacific air travel if the ash plume achieved flight levels. During most historical eruptions of Pavlof, pyroclastic material erupted from the volcano has interacted with the snow and ice on the volcano producing

volcanic mudflows or lahars. Lahars have inundated most of the drainages heading on the volcano and filled stream valleys with variable amounts of coarse sand, gravel, and boulders. The lahars are often hot and would alter or destroy stream habitat for many years following the eruption.

Other stratocones and vents within the Emmons Lake volcanic center are not known to have erupted in the past 300 years. However, young appearing deposits and lava flows suggest there may have been small explosions and minor effusive eruptive activity within the caldera during this time interval. Mount Hague may have experienced minor steam eruptions. The greatest hazards in order of importance are described below and summarized on plate 1.

\section{Volcanic-ash Clouds}

Clouds of fine volcanic ash produced during explosive eruptions will drift away from the volcano with the wind. Ash clouds are a hazard to all aircraft downwind of the volcano, and airborne volcanic ash can drift thousands of kilometers from its source. Ash from future eruptions could interfere with air travel, especially during a large sustained eruption.

\section{Volcanic-ash Fallout}

Ash fallout from eruptions of volcanoes in the Emmons Lake volcanic center can reach populated areas of the Alaska Peninsula and accumulations of fine ash several millimeters or more in thickness may occur. Should a large, explosive eruption occur, the zone of ash fall could extend over all parts of Alaska and possibly into western Canada. Fine ash is a nuisance and may cause respiratory problems in some humans and animals. Heavy ash fall can disrupt many human activities, interfere with

\section{THE ALASKA VOLCANO-HAZARD ASSESSMENT SERIES}

This report is part of a series of volcano-hazard assessment reports being prepared by the Alaska Volcano Observatory. The reports are intended to describe the nature of volcanic hazards at Alaska volcanoes and show the extent of hazardous areas with maps, photographs, and other appropriate illustrations. Considered preliminary, these reports are subject to revision as new data become available. 
power generation, affect visibility, and damage electrical components and equipment. Windblown ash could extend the unpleasant effects of ash fallout.

\section{Lahars, Lahar-runout Flows, and Floods}

Hot volcanic debris may interact with snow and ice to form fast-moving slurries and flows of water, mud, rocks, and sand. These flows, called lahars, are expected to form during most future eruptions of volcanoes in the Emmons Lake volcanic center, and at Pavlof Volcano in particular. Lahars and sediment laden floods follow streams and drainages and could flow to the coastline of either the Bering Sea or North Pacific Ocean depending on the location of the erupting vent. Lahars would be hazardous to anyone in a major drainage during an eruption.

\section{Pyroclastic Flow and Surge}

Hot volcanic debris expelled from the volcano during explosive eruptive activity may travel rapidly down the volcano flanks as a fast-moving flow of rock, gas, and ash. These flows, called pyroclastic flows and surges, travel mainly along valleys and low-lying topography. They are only hazardous to people and possibly low-flying aircraft on or near the volcano during an eruption.

Other hazardous phenomena that may occur but are uncommon during typical eruptions of the Emmons Lake volcanic center include: debris avalanches, directed blasts, volcanic gases, and lava flows.

\section{Debris Avalanche}

A debris avalanche is a rapidly moving mass of solid or incoherent blocks, boulders, and gravel initiated by a large-scale failure of the volcano flank. Debris-avalanche deposits have not been recognized at volcanoes in the Emmons Lake volcanic center and do not appear to be significant hazards.

\section{Directed Blasts}

A directed blast is a lateral explosion of the volcano caused by rapid release of internal pressure commonly caused by a slope failure or landslide. Directed blasts are rare volcanic events. Evidence for a directed blast has not been identified at the Emmons Lake volcanic center.

\section{Volcanic gases}

Some volcanoes emit gases in concentrations that are harmful to humans. Most of the vents in the Emmons Lake volcanic center are subject to frequent windy conditions that would likely prevent the buildup of volcanic gases. However, some of the craters, such as Hague, contain acid lakes and could contain gases that may build up to harmful levels. In general, the hazard from volcanic gases is minimal unless one is in the Hague crater or near the fumarolic areas on the flanks of Hague for prolonged periods of time.

\section{Lava flow}

Streams of molten rock (lava) may extend for several kilometers from one or more vents within Emmons Lake caldera and from other stratovolcanoes in the area. Lava flows typical of the area move slowly, only a few tens of meters per hour, and pose little hazard to humans. Some lava flows may develop steep, blocky fronts and avalanching of blocks could be hazardous to someone close to the flow front.

\section{SUGGESTIONS FOR READING THIS REPORT}

Readers who want a brief overview of volcano hazards at the Emmons Lake volcanic center are encouraged to read the summary section and consult plate 1 and the illustrations. Individual sections of this report provide a slightly more comprehensive overview of the various hazards at the Emmons Lake volcanic center. A glossary of relevant geologic terms is included. Additional information about the Emmons Lake volcanic center can be obtained by consulting the references cited at the end of this report or by visiting the Alaska Volcano Observatory web site (URL: 〈http://www.avo.alaska.edu〉). 


\section{Introduction}

The Emmons Lake volcanic center is a large stratovolcano complex on the Alaska Peninsula near Cold Bay, Alaska (fig. 1). The volcanic center is characterized by several iceand snow-clad stratovolcanoes that lie mostly inside a nested caldera complex that hosts Emmons Lake and truncates a shield-like ancestral Mount Emmons edifice. The main stratovolcanoes of the center (from northeast to southwest) are, Pavlof Sister, Pavlof, Little Pavlof, Double Crater, Mount Hague, and Mount Emmons (fig. 1). Several small cinder cones and vents are within Emmons Lake caldera; some have been the source of young lava flows that mantle the floor of the caldera. Pavlof Volcano, in the northeastern part of the volcanic center, is the most historically (about the past 300 years) active volcano in Alaska (Miller and others, 1998) and eruptions from Pavlof pose the greatest hazards to the region.

The Emmons Lake volcanic center is about $40 \mathrm{~km}$ east of Cold Bay, about $34 \mathrm{~km}$ northeast of King Cove, and about $95 \mathrm{~km}$ southwest of Sand Point. These are the largest towns and villages in the region. Nelson Lagoon, a small Bering Sea village primarily focused on commercial fishing and subsistence activities, is about $93 \mathrm{~km}$ northeast of Pavlof Volcano.

Cold Bay is an important support hub for the fishing industry and houses several federal offices that are associated with Aleutian transportation and wildlife protection. A state-owned, 3175-meter-long by 45-meter-wide, paved and lighted runway with a 1562-meter-long by 45-meter-wide, paved crosswind runway, an Federal Aviation Administration Flight Service Station, and a seaplane base are located in Cold Bay. Cold Bay is a regional transportation center, and provides scheduled flights to surrounding communities.

King Cove is also a year-round commercial fishing and seafood processing center, including one of the largest cannery operations under one roof in Alaska. Up to 500 non-residents come to King Cove to work for the cannery as needed.

Sand Point is an important regional fishing port and supports a large fishing fleet. The State of Alaska provides regional services through the Department of Public Safety, Department of Fish and Game, and the Alaska Court system.

Most of the area around the Emmons Lake volcanic center is uninhabited wilderness within the Izembek National

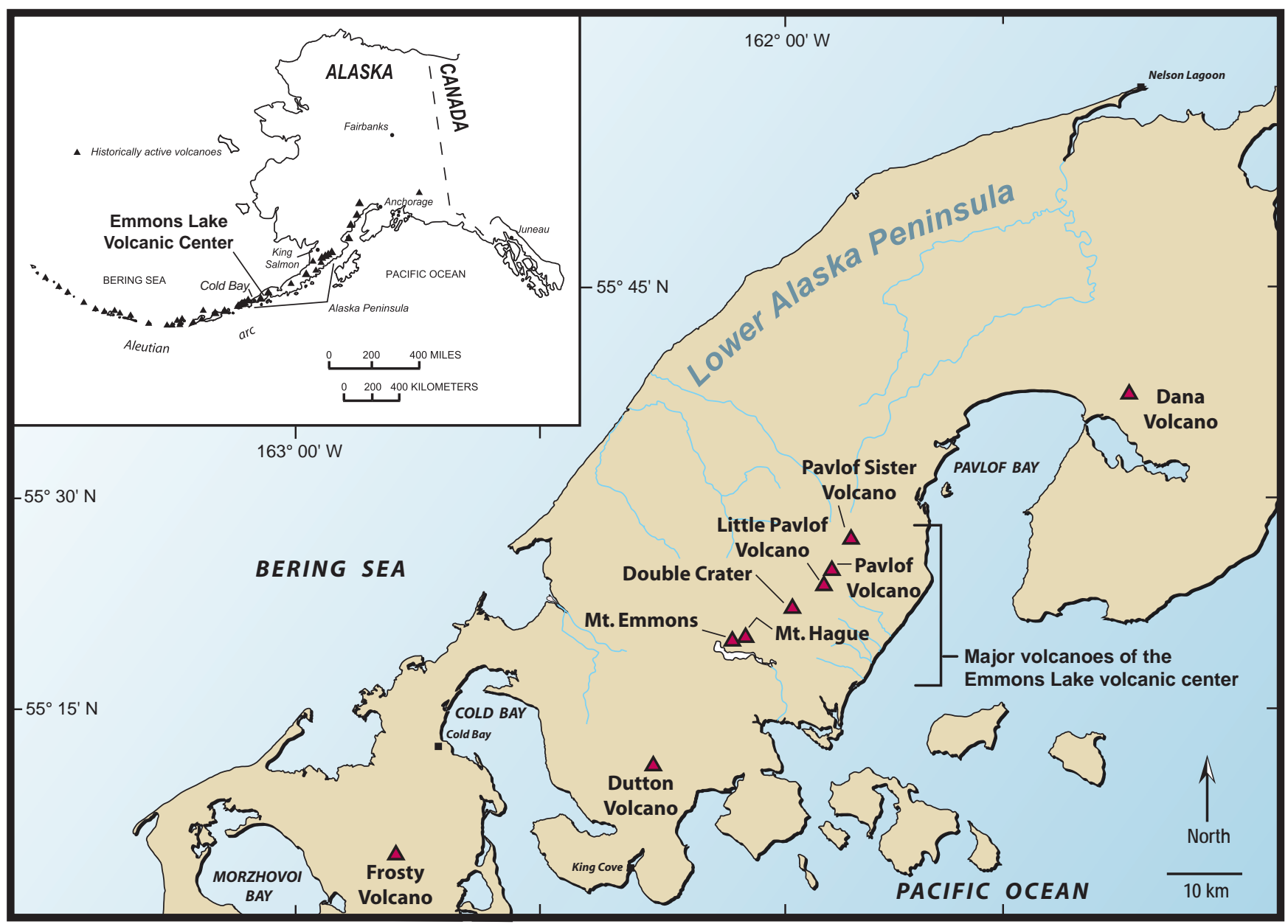

Figure 1. Location of the Emmons Lake volcanic center on the Alaska Peninsula of southwestern Alaska and major stratocones in the region. 
Wildlife Refuge. This remote wilderness region is known for its large concentrations of migratory birds, particularly the Pacific Black Brandt. The area is rugged and largely inaccessible, except by aircraft. Because of the remote location, recreational use of the area is minimal, although small groups of people visit in the summer and winter. Life and property are not at risk in the immediate vicinity of the Emmons Lake volcanic center.

The Emmons Lake volcanic center forms a northeast-southwest trending cluster of volcanic cones and vents that include lava flows and pyroclastic deposits that range in composition from basalt to dacite. Emmons Lake caldera is among the largest known in the Aleutian arc. It is a nested complex of intersecting calderas that formed during at least three large, voluminous, and explosive eruptions. Eruptive products from these eruptions range in composition from dacite to rhyolite. Volcanic ash from the most recent caldera-forming eruption (about 26,000 years ago) is found near Dawson in the Yukon, about $1700 \mathrm{~km}$ northeast of the Emmons Lake volcanic center.

\section{Purpose and Scope}

This report summarizes the principal volcano hazards associated with eruptions from the Emmons Lake volcanic center and provides new information about the area since an earlier U.S. Geological Survey study by Kennedy and Waldron (1955). Hazardous volcanic phenomena likely to occur during any type of eruptive activity, as well as distal effects of eruptions, are described. Also presented are the current status of monitoring efforts to detect volcanic unrest and the procedures for eruption notification and information dissemination. The report includes a series of maps and illustrations showing potentially hazardous areas and a glossary of geologic terms used in the report. By convention, metric units are used throughout the report. To assist readers, a conversion table with English units is provided on page vi.

\section{Physical Setting of the Emmons Lake Volcanic Center}

The Emmons Lake volcanic center includes a variety of volcanic cones, vents, and features that formed during more than 400,000 years of energetic volcanism in the area. The volcanic center consists of a large stratovolcano complex that contains at least three nested caldera structures-collectively referred to as "Emmons Lake caldera" in subsequent parts of the report. A variety of intracaldera vents and cones and a string of relatively large post-caldera ice- and snow-clad stratovolcanoes extend northeast beyond the caldera rim (fig. 2). The three calderas record major explosive silicic eruptions of Quaternary age (the past 1.8 million years) from within the volcanic center.

A prominent but discontinuous topographic scarp marks one or more of the caldera boundaries. The caldera rim elevation ranges from about $915 \mathrm{~m}$ above sea level southwest of Emmons Lake to $2060 \mathrm{~m}$ above sea level at Little Pavlof volcano on the northeast margin. The scarp above Emmons Lake exposes about $600 \mathrm{~m}$ of thickbedded lava flows and volcaniclastic rocks that make up ancestral Emmons Lake volcano. The caldera complex is breached on both its north and south sides (fig. 2) and lava flows of Holocene age extend through these gaps. The north side breach is about $3 \mathrm{~km}$ wide and it contains headwaters of the upper Cathedral River drainage. The breach on the south side, informally referred to as the "gap", is a 9-km-wide trough that includes an unnamed river draining Emmons Lake. At least four geologically significant silicic welded tuff units have flowed through the gap within the past 234,000 years. Glacier ice and glacial moraine cover large parts of the floor of the caldera complex.

The Volcano Bay caldera forms a less prominent feature in the area south of Emmons Lake (fig. 2). This informally named caldera is represented by a prominent scarp-like, east-west trending topographic ridge truncated at its east edge by the Emmons Lake drainage and the "gap". The scarp is less clearly defined at the extreme south edge of the caldera complex as it decreases in elevation and is hidden beneath

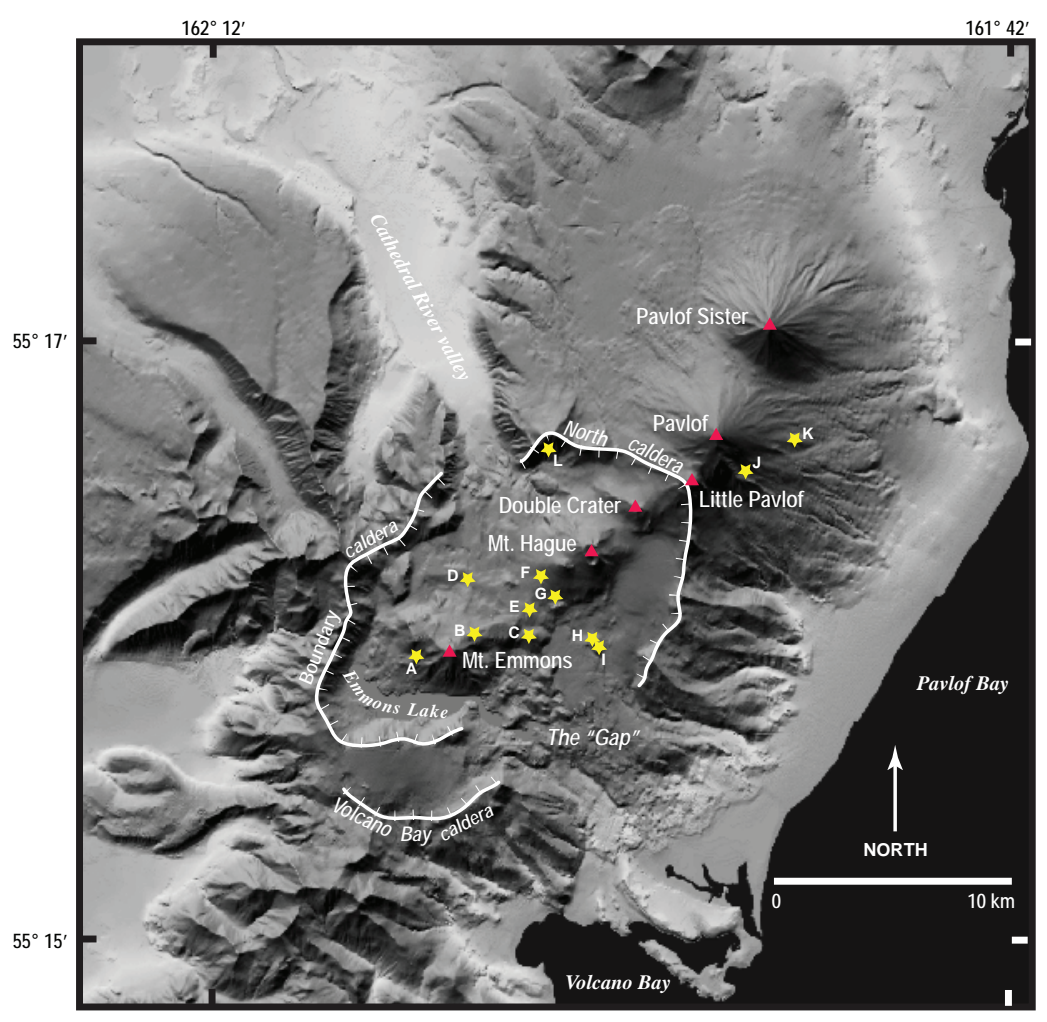

Figure 2. Major volcanic features, structures, and stratocones within the Emmons Lake volcanic center. Cinder cones labeled A-L modified from Kennedy and Waldron, 1955. 
glacier ice. It is older than, and truncated by, the scarp around Emmons Lake.

Mount Emmons $\left(55^{\circ} 20.45^{\prime} \mathrm{N}, 162^{\circ} 4.35^{\prime} \mathrm{W}\right.$; summit altitude $1325 \mathrm{~m}$ ) is the westernmost stratocone within the caldera complex (fig. 3). This snow- and ice-clad volcano is primarily an andesite cone with minor basaltic andesite and low-silica dacite lavas. Mount Emmons has a glaciallyscoured base and has had no known historical eruptions.

Mount Hague $\left(55^{\circ} 22.73^{\prime} \mathrm{N}, 161^{\circ} 58.44^{\prime}\right.$; summit altitude $1540 \mathrm{~m}$ ) is the largest (approximate volume $=5 \mathrm{~km}^{3}$ ) and most prominent of the intracaldera volcanic vents. Mount Hague consists of a twin-peaked andesitic stratovolcano about 5 $\mathrm{km}$ wide at the base and about $750 \mathrm{~m}$ high. The flanks of Mount Hague are mantled by snow and ice and the north crater contains a small slab-like glacier (fig. 4). Two intersecting circular craters, each about $400 \mathrm{~m}$ in diameter, form the summit area. The highest point along the rim of the northern crater is $1540 \mathrm{~m}$ above sea level. The northern crater cuts the southern crater, suggesting the southern crater is younger. The southern crater is about $250 \mathrm{~m}$ deep and contains a steaming, acidic ephemeral lake (fig. 4b). The lake intermittently drains into the edifice revealing a vigorous fumarole field on the crater floor. A second fumarole field is located on the southeast flank of Mount Hague $\left(55^{\circ} 22.37^{\prime} \mathrm{N}, 161^{\circ} 58.12^{\prime} \mathrm{W}\right)$ in a steep, incised ravine at an elevation of about $975-1160 \mathrm{~m}$ above sea level (fig. 4a). Several vigorously steaming vents are present in the ravine and precipitation of native sulfur has formed pinnacle-like columns around some of the vents. The fumarole field in the ravine is about $700 \mathrm{~m}$ from the fumaroles in the summit crater. Both fumarole fields are at about the same elevation. Steam plumes originating from the Mount Hague crater or the fumarole fields are often visible from Cold Bay and King Cove. These plumes are often erroneously attributed to nearby Pavlof Volcano (McGimsey, and others, 2005; Neal, and others., 2004), and are sometimes mistaken for ash clouds.

Double Crater $\left(55^{\circ} 23.95^{\prime} \mathrm{N}, 161^{\circ} 56.65^{\prime} \mathrm{W}\right.$; summit altitude $1357 \mathrm{~m}$ ) is in the eastern part of the North caldera, just east of Mount Hague (fig. 2). Double Crater has a nested set of two small craters at the top of a mostly snow and ice covered stratocone (fig. 5). No known historical activity has occurred from this vent, but activity of Holocene age is suspected because of the fresh appearing morphology of the summit craters. The lavas that make up Double Crater are andesite in composition.

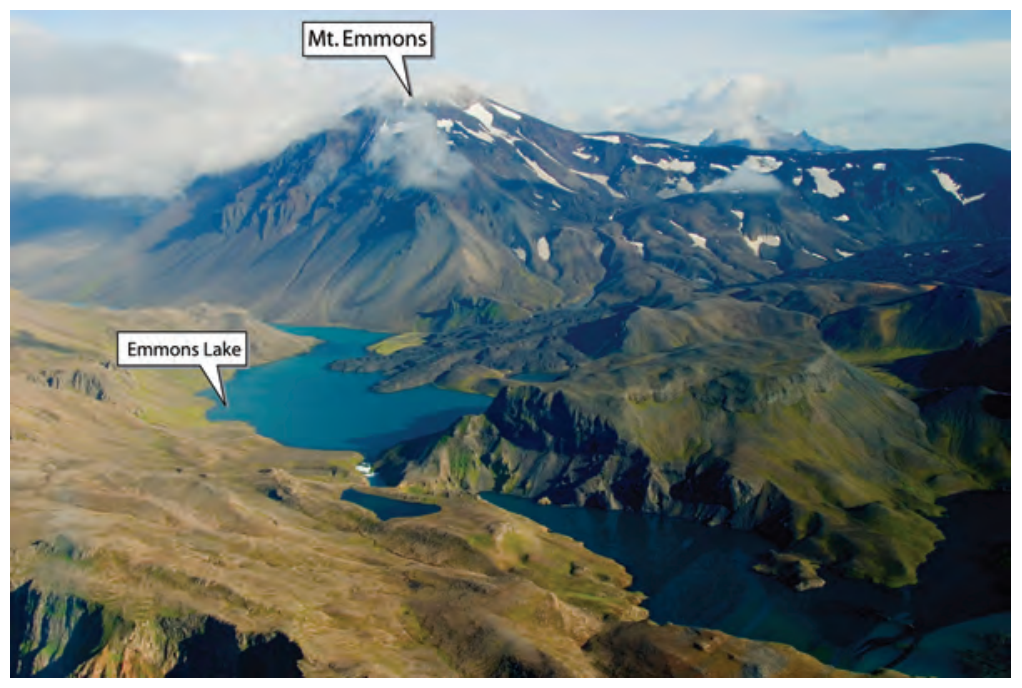

Figure 3. Photograph of Mt. Emmons and Emmons Lake. View is to the north. Photograph by C.F. Waythomas, August 2003.
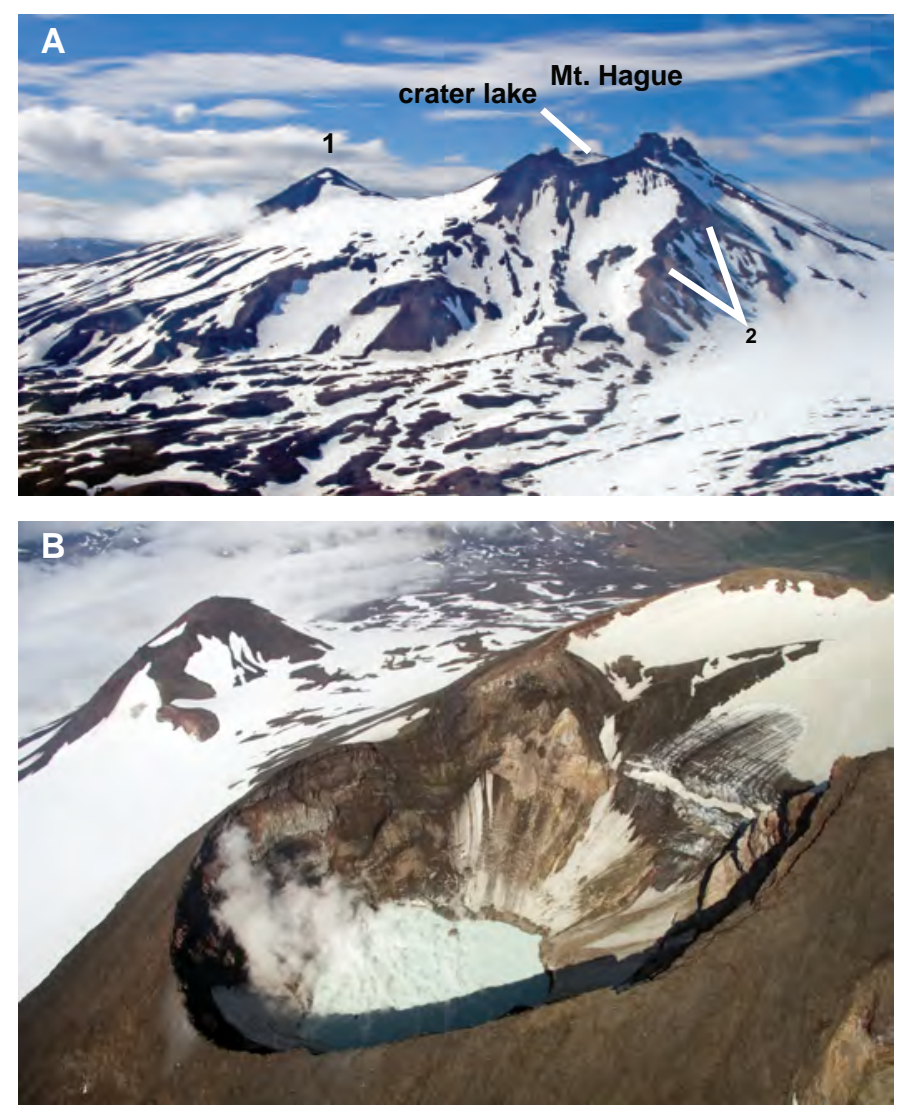

Figure 4a. Photograph of Mount Hague, an unnamed stratocone northwest of Hague (1), and location of fumaroles (2) on southeast flank. View is to the northeast. Photograph by C.F. Waythomas, August 2005.

Figure 4b. Photograph of southern crater of Mount Hague showing steaming ephemeral lake. Photograph by C.F. Waythomas, August 2003. 


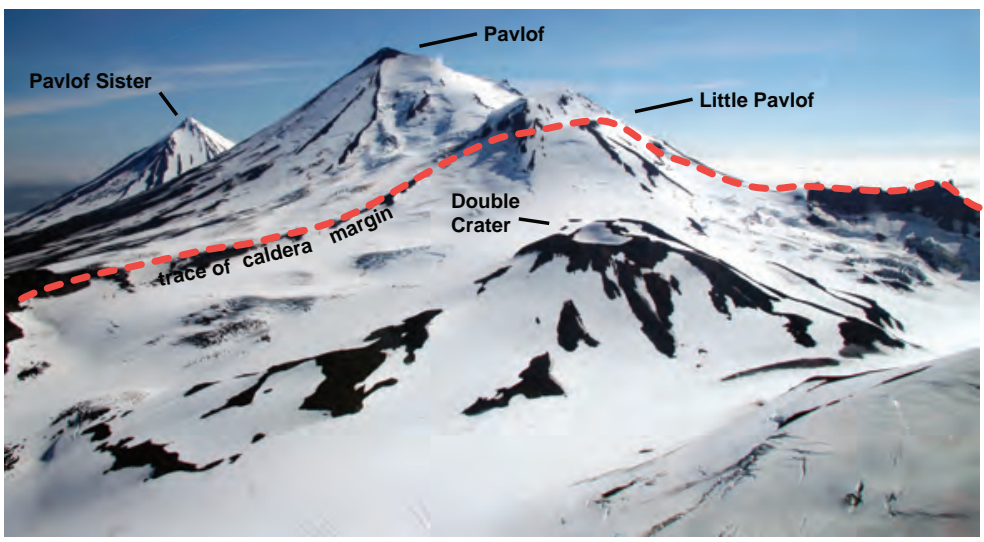

Figure 5. Photograph of Double Crater, Little Pavlof, Pavlof, and Pavlof Sister volcanoes. View is to the east. Also indicated is eastern margin of the North caldera. Photograph by C.F. Waythomas, August 2005.

Little Pavlof Volcano (55²4.01'N, 161 '54.63'W; summit altitude $2042 \mathrm{~m}$ ) is located on the eastern rim of the north caldera on the upper west flank of Pavlof Volcano (fig. 2). Little Pavlof is a small ice- and snow-covered satellite cone with a dome-shaped summit. This volcano is difficult to reach because of its extensive snow and ice cover and steep flanking slopes. Consequentially, little is known about Little Pavlof's eruptive history and geology. Limited sampling of lava flows on Little Pavlof shows the cone consists of basalt and andesite.

Pavlof Volcano $\left(55^{\circ} 25.00^{\prime} \mathrm{N}, 161^{\circ} 53.25^{\prime} \mathrm{W}\right.$; summit altitude $2518 \mathrm{~m}$ ) is a snow- and-ice-covered, symmetrical cone-shaped stratovolcano located northeast of Emmons Lake caldera (fig. 2). The volcano is the most active volcano in the Aleutian arc (Miller and others, 1998) and its flanking slopes are extensively mantled with tephra and pyroclastic debris produced during historical eruptions. Eruptive products are mostly andesite to basaltic andesite and rare basalt. Strombolian eruptions and lava fountaining are the most common eruptive style. The summit vent orientation changes periodically at the start of a new eruption, shifting between northerly and southerly locations. At present, Pavlof has a small, north facing crater located a few hundred meters from the summit. Because the volcano supports an extensive snow and ice cover (fig. 5), most historical eruptions are associated with volcanic mudflows or lahars. Thus, laharic debris chokes most of the drainages that head on the volcano.

Pavlof Sister $\left(55^{\circ} 27.18^{\prime} \mathrm{N}, 161^{\circ} 50.58^{\prime} \mathrm{W}\right.$; summit altitude $2142 \mathrm{~m}$ ) is also a snow- and-icecovered, symmetrical, cone-shaped stratovolcano just east of Pavlof Volcano (fig. 2). Pavlof Sister is similar in many regards to Pavlof Volcano (fig. 6). However, it is smaller and has had no known historical eruptions. Its flanking slopes are mantled by an extensive cover of tephra and pyroclastic debris and the volcano is slightly dissected by glacier ice and stream erosion. The lava flows that make up Pavlof Sister are basaltic andesite in composition. The volcanic products exposed on the flanks of the volcano indicate the volcano has had mostly Strombolian and lava fountain eruptions.

At least twelve large, black to red cinder cones (labeled A-L on fig. 2) are present within the Emmons Lake volcanic center mostly on the floor of the caldera complex. These cinder cones are variably oxidized cinder, scoria, and agglutinate of basaltic-andesite to andesite composition. The cones appear monogenetic and have symmetric or crescent-shaped, unvegetated, flanking slopes at about the angle of repose suggesting they are relatively young in age, and some may have been active historically. Lava flows of Holocene age have erupted through breaches in cones A, D, F, and G.

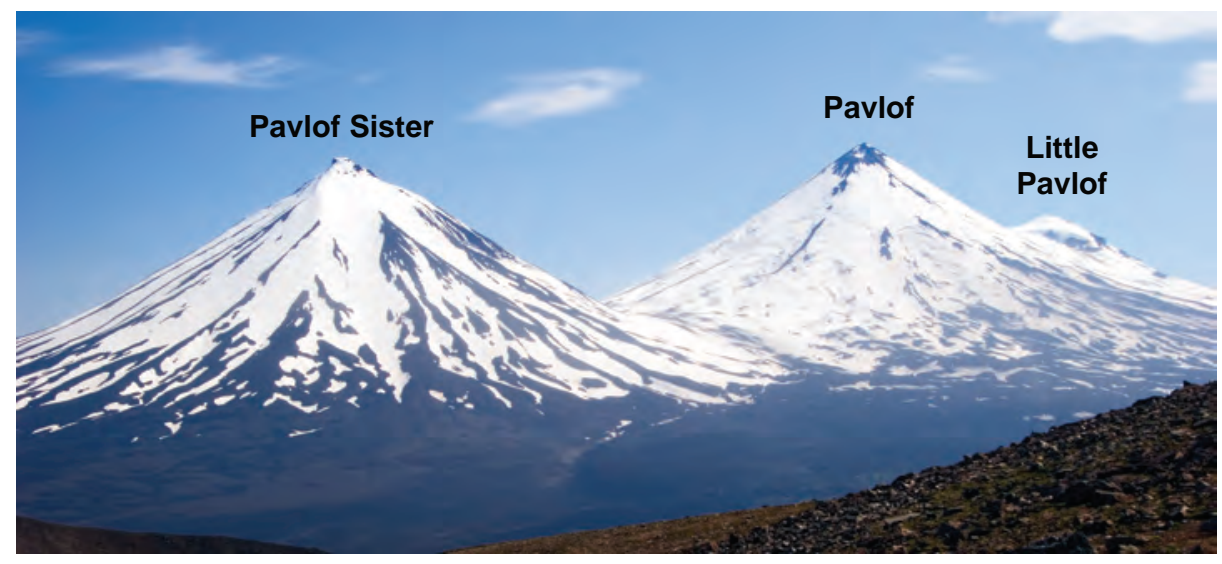

Figure 6. Photograph of Pavlof Sister and Pavlof volcanoes. View is to the southwest. Photograph by C.F. Waythomas, August 2005. 


\begin{tabular}{|c|c|c|c|c|}
\hline $\begin{array}{c}\text { AGE } \\
\text { (years B.P.) }\end{array}$ & MAJOR VOLCANIC EVENTS & $\begin{array}{l}\text { PRIMARY GEOLOGIC UNITS } \\
\text { AND FEATURES }\end{array}$ & TYPE OF ACTIVITY & EXPLANATION \\
\hline \multicolumn{5}{|c|}{${ }^{0}$} \\
\hline 10,000 & Intra-caldera eruptions & Lava flows, stratocones & Vulcanian to Strombolian eruptions & $\begin{array}{l}\text { Explosive ejection of incandescent lava and ash. } \\
\text { Eruptive bursts last from seconds to minutes. }\end{array}$ \\
\hline 25,000 & $\begin{array}{l}\text { Caldera-forming eruption } \\
\text { Intra-caldera eruption }\end{array}$ & $\begin{array}{l}\text { Pumice pyroclastic flows } \\
\text { Welded tuff }\end{array}$ & $\begin{array}{l}\text { Major Plinian/ulta-Plinian eruption } \\
\text { Extensive ignimbrite sheets } \\
\text { Large Plinian eruption }\end{array}$ & $\begin{array}{l}\text { Major explosive events with high column of } \\
\text { ash and pyroclastic debris. Extensive ash } \\
\text { dispersal and formation of mobile and far } \\
\text { traveling pyroclastic flows. }\end{array}$ \\
\hline \multicolumn{5}{|l|}{50,000} \\
\hline 100,000 & $\begin{array}{l}\text { Intra-caldera eruption } \\
\text { Caldera-forming eruption }\end{array}$ & $\begin{array}{l}\text { Lava domes, welded tuff } \\
\text { Gap welded tuff }\end{array}$ & $\begin{array}{l}\text { Large Plinian eruption } \\
\text { Major Plinian/ulta-Plinian eruption } \\
\text { Extensive ignimbrite sheets }\end{array}$ & $\begin{array}{l}\text { Major explosive events with high column of } \\
\text { ash and pyroclastic debris. Extensive ash } \\
\text { dispersal and formation of mobile and far } \\
\text { traveling pyroclastic flows. }\end{array}$ \\
\hline \multicolumn{5}{|l|}{200,000} \\
\hline 300,000 & $\begin{array}{l}\text { Caldera-forming eruption } \\
\text { Caldera-forming eruption }\end{array}$ & $\begin{array}{l}\text { Cathedral welded tuff } \\
\text { Leontovich welded tuff }\end{array}$ & $\begin{array}{l}\text { Major Plinian/ulta-Plinian eruption } \\
\text { Extensive ignimbrite sheets } \\
\text { Major Plinian/ulta-Plinian eruption } \\
\text { Extensive ignimbrite sheets }\end{array}$ & $\begin{array}{l}\text { Major explosive events with high column of } \\
\text { ash and pyroclastic debris. Extensive ash } \\
\text { dispersal and formation of mobile and far } \\
\text { traveling pyroclastic flows. }\end{array}$ \\
\hline 500,000 & Cone-building phase & $\begin{array}{l}\text { Lava flows } \\
\text { Volcaniclastic rocks }\end{array}$ & $\begin{array}{l}\text { Construction of the ancestral } \\
\text { Emmons cone } \\
\text { Many small-to-moderate eruptive events }\end{array}$ & $\begin{array}{l}\text { Mostly lava producing eruptions and occasional } \\
\text { explosive activity and some lahar activity. }\end{array}$ \\
\hline
\end{tabular}

Figure 7. Summary of the major volcanic events at the Emmons Lake volcanic center as determined by recent geologic and geochronologic studies.

\section{Prehistoric Eruptive Activity}

Geologic mapping, petrologic studies, and radiometric age dating indicate that volcanic activity at the Emmons Lake volcanic center has been dominated by three to six major caldera-forming eruptions from about 400,000 to about 26,000 years ago (fig. 7). Before the first caldera-forming eruption occurred, the volcanic edifice consisted of a large, broad, relatively low-relief, shield-like cone or cone complex composed primarily of lava flows of basaltic andesite and various volcaniclastic rocks (fig. 8). The age of earliest volcanism is unknown, but it is likely that the center was intermittently active for several hundreds of thousands of years before the first caldera forming eruption occurred about 400,000 years B.P.

Eruptive product studies associated with caldera formation date the major eruptions around 294,000, 234,000, $123,000,100,000,30-50,000$, and 26,000 years ago. Each of these eruptions produced relatively extensive pyroclasticflow deposits of dacite to rhyolite composition hot enough to weld when deposited and form the welded tuff units shown in figures 7 and 8 . Some of the welded tuffs show evidence of secondary flowage (rheomorphic tuffs) as far as $35 \mathrm{~km}$ from their source calderas (fig. 8). Rheomorphic welded tuffs are unique to the Emmons Lake volcanic center and are found nowhere else in the Aleutian arc. The welded tuffs crop out in areas southeast and northeast of the caldera complex where they flowed into and filled preexisting valleys and ancestral drainages. In contrast, the 26,000-year-old event, produced non-welded, highly mobile, pumice-rich pyroclastic flows of rhyolitic composition. The flows crop out over an area of about $3000 \mathrm{~km}^{2}$ surrounding the Emmons Lake volcanic center and up to $60 \mathrm{~km}$ from the caldera. A rhyolitic ash fall deposit found $1700 \mathrm{~km}$ away in the Klondike region of northwestern Canada has been correlated with the 26,000-year-old event at the Emmons Lake volcanic center (Mangan and others, 2003).

At least two distinct episodes of intra-caldera andesitic volcanism have been documented at the Emmons Lake volcanic center. During the first episode, at least four andesitic lava flows were erupted between the Volcano Bay and Boundary calderas in the southernmost part of the caldera complex (unit 


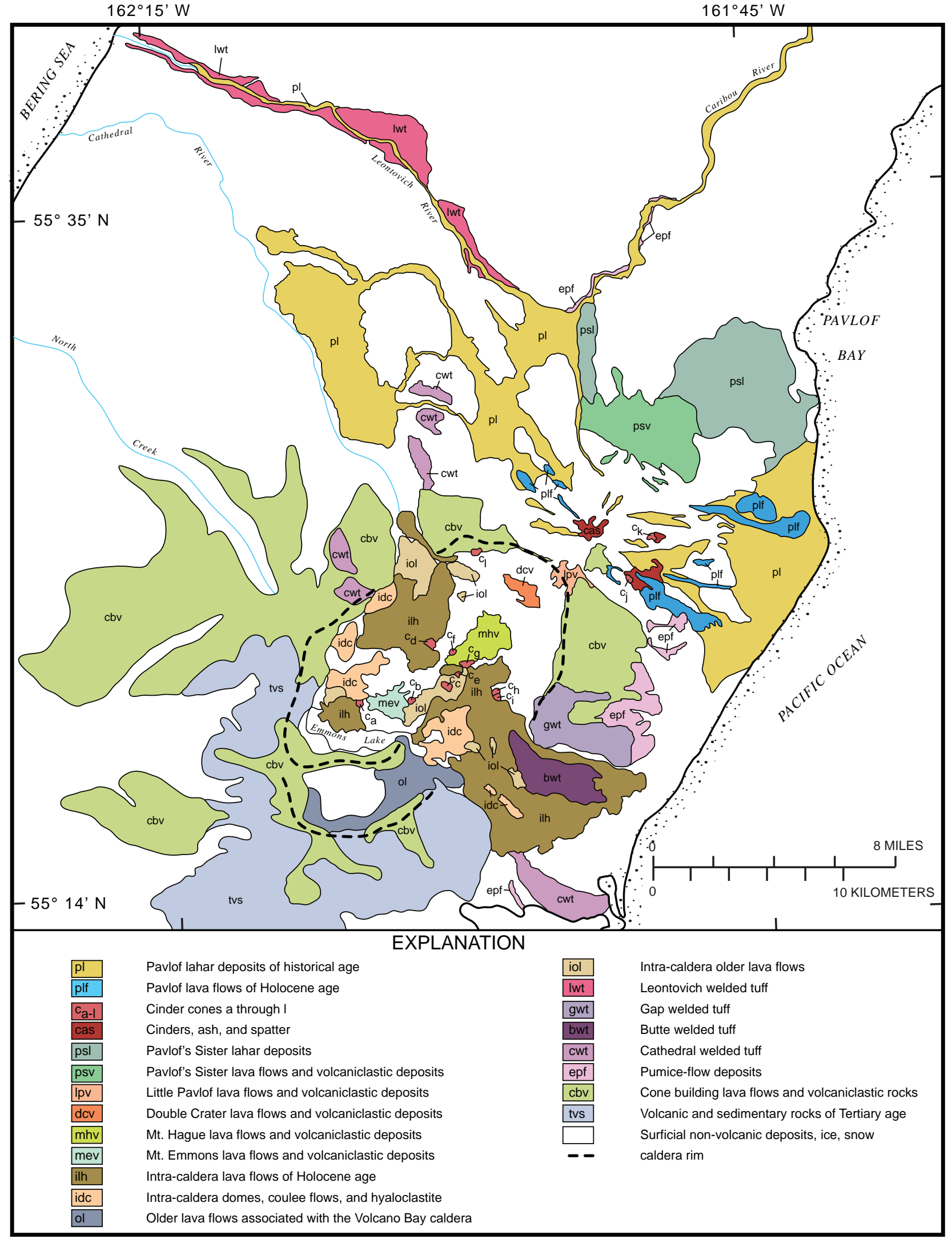

Figure 8. Simplified geologic map of the Emmons Lake volcanic center. 
ol, fig. 8) about 126,000 years B.P. During the second episode of intra-caldera volcanism, a northeast-southwest trending cluster of stratovolcanoes and associated cinder cones and lava flows were erupted. This included the main stratocones of Mount Emmons, Mount Hague, Double Crater, Pavlof, and Pavlof Sister. Except for Mount Emmons and Little Pavlof, none of these stratocones has been obviously eroded by glacier ice, suggesting that all of them formed since the area was last glaciated during the late Pleistocene, or roughly since about 15,000 to 20,000 years ago. Thus, this second episode of intra-caldera volcanism includes activity probably underway by 20,000 years ago to the period of historical eruptive activity covering about the past 300 years.

Mount Hague Volcano and cinder cones C, D, E, F, G, and $\mathrm{L}$ have been the source of at least 20 basaltic andesite to andesitic lava flows. These flows moved across parts of the caldera floor and out through the northern and southern gaps in the caldera rim. Some of these flows traveled to within $3 \mathrm{~km}$ of the Pacific Ocean. These lava flows cover an area of about $70 \mathrm{~km}^{2}$ and have not been glaciated and have little to no vegetation cover. Although we have been unable to determine radiometric ages on these lava flows, their morphology and weathering characteristics indicate that they are likely Holocene in age.

\section{Historical Eruptive Activity}

The weather conditions and remote setting of the Alaska Peninsula inhibit continuous observations and viewing of volcanic activity. Thus, many of the early reports of historical eruptive activity from volcanoes and cinder cones in the Emmons Lake volcanic center are limited because few people have lived in the area, and observations are often hampered by bad weather. It is possible for activity at one location to be mistaken for activity elsewhere since the volcanoes in the center are close together. From certain viewing angles it can be difficult to tell which volcano is showing signs of activity.

Pavlof Volcano is the most active volcano in the Emmons Lake volcanic center and is also the most active volcano in the Aleutian volcanic arc. Although the exact number of historical eruptions of Pavlof is unknown for the reasons given above, eyewitnesses report at least 40 eruptions since 1790 (table 1; Miller and others, 1998). Most of these eruptions were relatively modest Strombolian events that produced minor amounts of ash, small lava flows, and localized pyroclastic flows and lahars. Occasionally, lava fountaining has occurred, resulting in spatter accumulation lower on the flanks of the volcano. During some eruptions, the spatter piles were large enough to evolve to rootless, clast-rich lava flows that extended several kilometers down the north and south flanks of the volcano. These lava flows and some of the pyroclastic flows that formed during the more explosive phases of individual eruptions were emplaced on snow and glacier ice. This led to extensive lahar and lahar runout flows in several of the drainages heading on Pavlof Volcano. During several historical eruptions, lahar runout flows reached the Bering Sea and north Pacific Ocean.

Although Strombolian eruptions and low-level ash emission have been common during historical eruptions of Pavlof Volcano (fig. 9), occasionally the volcano erupts ash explosively, and there have been several ash plumes rising to $9100 \mathrm{~m}$ (30,000 feet) or more (Miller and others., 1998; McNutt, 1987). Thus, drifting ash clouds may pose a hazard to both local and regional aircraft.

Although none of the historical eruptions of Pavlof Volcano are well documented, the two best documented eruptions are the 1986-88 and the 1996-97 eruptions. Neal and McGimsey (1997), described the 1996-97 eruption and Yount and others (1989) provided a narrative of the 1986 eruption.

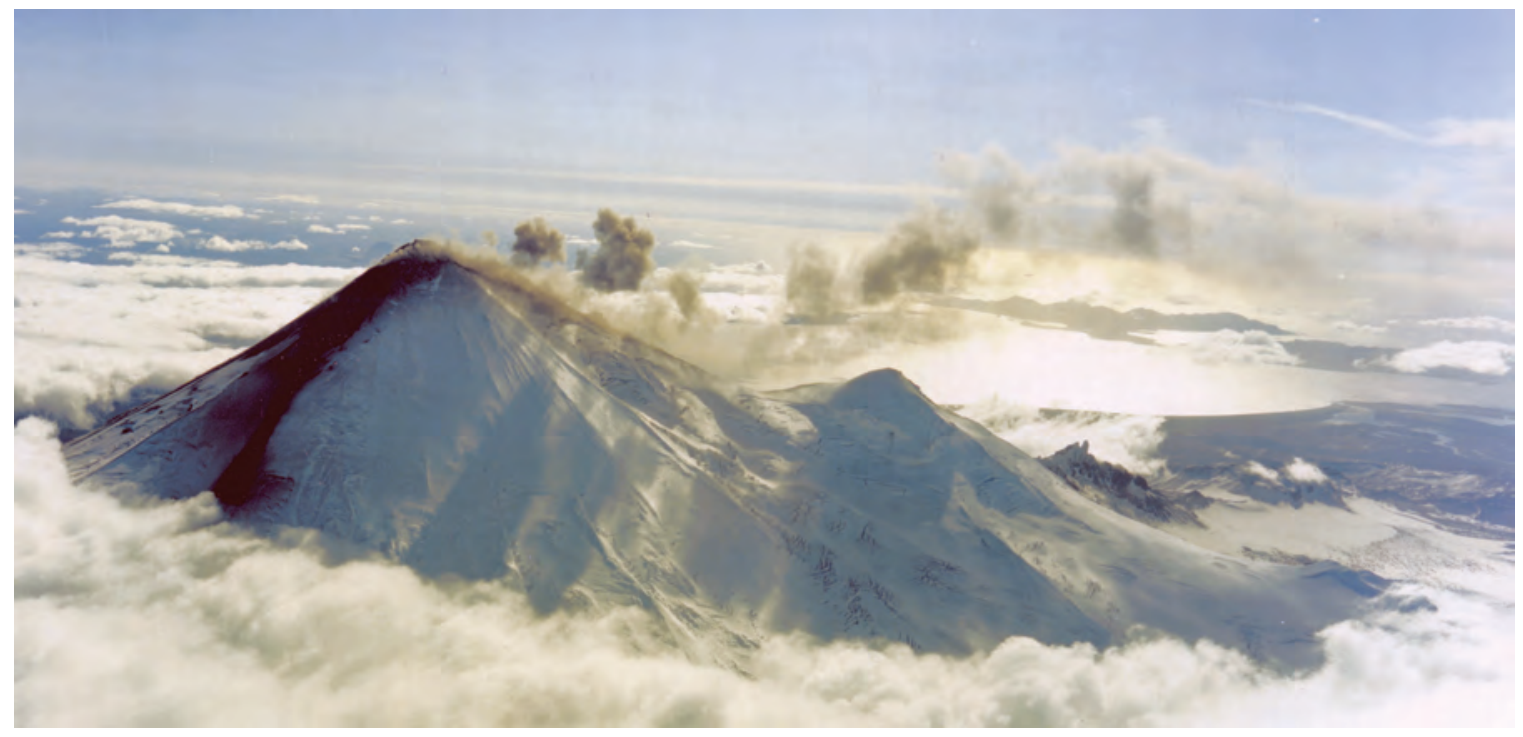

Figure 9. Photograph of Pavlof Volcano during a Strombolian eruption in 1996. Photograph by AeroMap, Inc. 
The 1996-97 eruption began in September 1996 and was probably underway at a low level as early as September 11. Residents of Cold Bay and King Cove observed Strombolian eruptive activity at the summit and pilots reported seeing large incandescent bombs and ballistic showers, and low-level ash and steam emissions extending about $2 \mathrm{~km}$ above the volcano. By the end of September 1996, lava fountaining was occurring from two vents within the roughly 150 -meter-diameter summit crater about $100 \mathrm{~m}$ below the summit (fig. 10). A small spatter cone formed around the vent on the west side of the crater and spatter-fed flows, and small lahars began to develop on the upper northwest flank. As the eruption progressed, accumulation and remobilization of spatter continued to feed the lava flow associated with the western vent. The lava flow eventually reached the base of the cone and melted a narrow channel in the snow and glacier ice cover. Melt water produced by this lava flow, and one associated with the eastern vent, resulted in watery lahars that inundated drainages to the north of the volcano, particularly the Leontovich and Caribou Rivers (fig. 8). By late October 1996, a second lava flow erupted from the east vent producing a lahar that flowed northeast close to the base of the Pavlof cone along the saddle between Pavlof and Pavlof Sister. After December 29, 1996, activity decreased and only occasional low-level ash and steam bursts were observed. No ash emission was reported after about February 6, 1997, indicating the eruption had essentially ended.

The 1996-97 eruption produced several diffuse ash clouds extending as far as $350 \mathrm{~km}$ downwind of the volcano, but rarely more than $6 \mathrm{~km}$ above sea level. Reports of light ash fall came in from King Cove during the evening of October 5-6, 1996. Reports were received from Sand Point on October 19, 1996, and Nelson Lagoon on October 28, 1996. A sample of ash collected in Sand Point was fine grained, black, and andesitic in composition (Neal and McGimsey, 1997).

The 1986 eruption began on April 16 and continued until about August 21. The eruption was characterized by intermittent Strombolian activity, lava fountaining, and occasional strong ash bursts that sent ash clouds $5-15 \mathrm{~km}$ above sea level on several occasions. As during the 1996 eruption, accumulation of spatter high on the northwest flank of Pavlof led to spatter-rich lava flows that flowed onto the snow and glacier ice on the upper flanks of the Pavlof cone. Melt water remobilized loose ash and pyroclastic debris and formed extensive lahars that inundated the upper Cathedral River drainage and other areas at the base of the volcano. During the eruption, a new vent opened on the upper east flank of the volcano, and it also produced spatter-fed lava flows that descended the east flank where they produced lahars that reached the base of the cone.

The largest historical eruption of Pavlof Volcano occurred in December 1911 (McNutt, 1987). This event produced violent explosions and earthquakes felt as far as Unga Island, about $95 \mathrm{~km}$ to the southeast. Pyroclastic flows developed, lava flows formed, and a small portion of the upper north flank may have been removed by the explosive activity.

Reports of historical eruptive activity from other volcanoes in the Emmons Lake volcanic center are unknown or considered unreliable. Steaming from Mount Hague is often

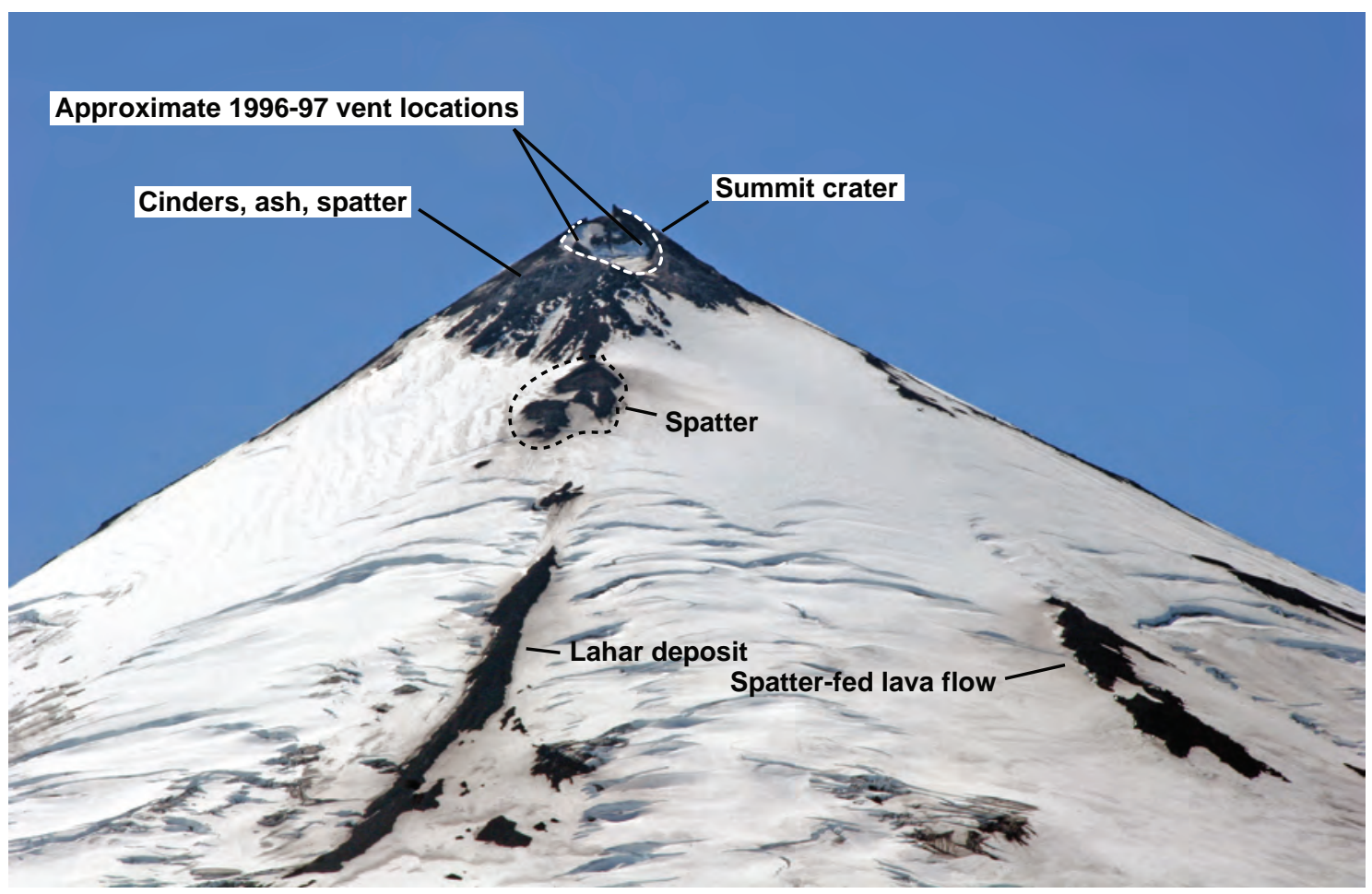

Figure 10. Photograph of summit area of Pavlof Volcano, showing 1996 vent, areas of spatter accumulation, and 1996 lahar deposit. View is to the southeast. Photograph by C.F. Waythomas, August 2005. 
reported (Neal and McGimsey, 1997) and the crater lake and flank fumaroles are possible sources; however, no confirmed historical eruptive activity has been documented at Hague. Several of the intracaldera cinder cones have fresh-appearing, flanking, unvegetated slopes suggesting they may have experienced some recent eruptive activity. However, as with Mount Hague, no documented reports of eruptions exist for these vents.

\section{Hazardous Phenomena Associated with Eruptions}

A volcano hazard (fig. 11) is any volcanic phenomenon that is potentially threatening to life or property. In general, hazards associated with volcanic eruptions are grouped as proximal or distal, relative to the areas most likely to be affected by specific volcanic phenomena as a function of distance from the vent (table 2). The classification of hazardous phenomena at the Emmons Lake volcanic center as proximal or distal is an approximate classification because the extent of a particular hazard is in part related to the scale of the eruption. Thus, a large eruption may cause some phenomena to affect areas well beyond the volcano, whereas during a smaller eruption, the same phenomena may affect areas only in the immediate vicinity of the volcano.

Proximal hazards are those phenomena that occur in the immediate vicinity of a volcano, typically within five to ten kilometers of the active vent (plate 1). Life and property within the proximal hazard zone may be at risk during eruptions depending on the eruptive style and duration of activity. Anyone in this zone would have little or no time to escape from the area in the event of an eruption. Because most of the

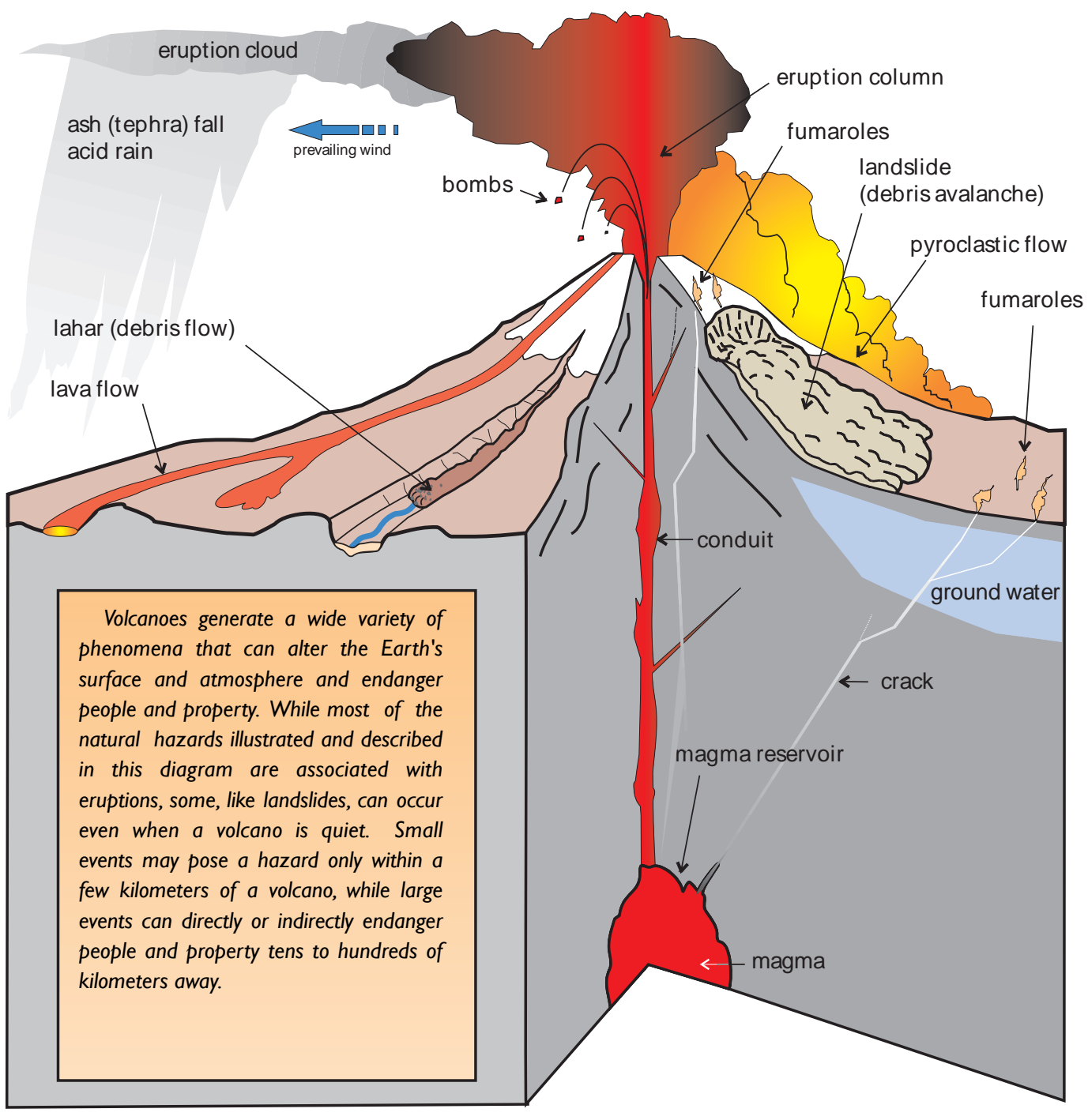

Figure 11. Schematic diagram showing volcanic processes and hazards at stratovolcanoes. 
Table 1. Outline of Historical Eruptive Activity for Pavlof Volcano. Information compiled by C. Cameron, Alaska Division of Geological and Geophysical Surveys and Alaska Volcano Observatory. Also available at www.avo.alaska.edu.

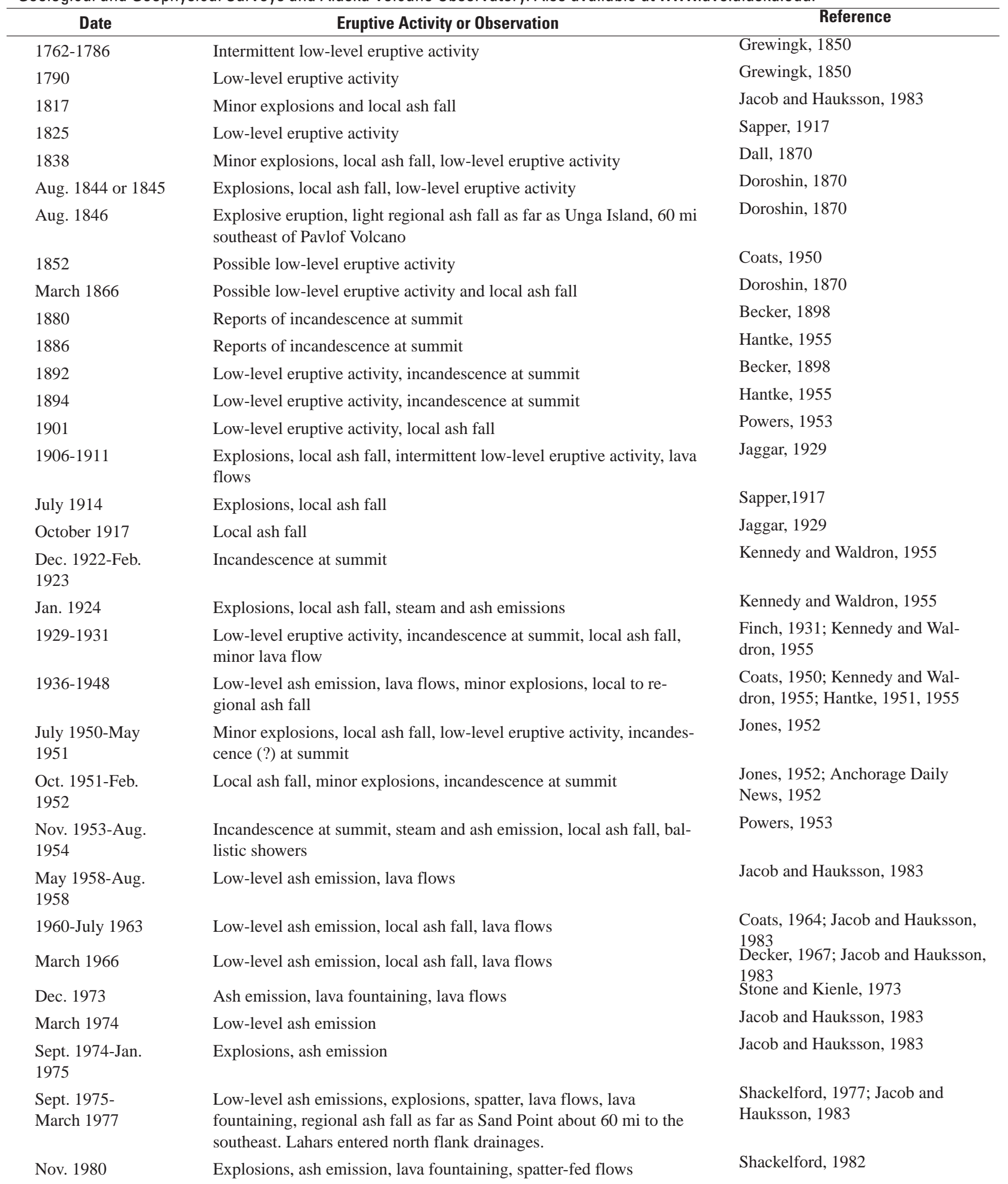


Table 1. Outline of Historical Eruptive Activity for Pavlof Volcano. Information compiled by C. Cameron, Alaska Division of Geological and Geophysical Surveys and Alaska Volcano Observatory. Also available at www.avo.alaska.edu.-Continued

\begin{tabular}{lll}
\hline \multicolumn{1}{c}{ Date } & \multicolumn{1}{c}{ Eruptive Activity or Observation } & \multicolumn{1}{c}{ Reference } \\
\hline Sept. 1981 & $\begin{array}{l}\text { Explosions, ash emission, regional ash fall as far as Unga Island about } \\
60 \text { mi to the southeast, incandescence at summit, spatter-fed flows on } \\
\text { northeast flank }\end{array}$ & McNutt, S., and Shackelford, 1983 \\
& Explosions, ash emission, incandescence at summit & Miller and McNutt, 1986 \\
July 1983 & Explosions, ash emissions & Reeder, 1990 \\
Nov.-Dec. 1983 & Ash and steam emissions, lava flows, lahars entered south flank drain- & Neal and McGimsey, 1997 \\
April 1986-Aug. & ages, lava fountaining & \\
1988 & Incandescence at summit, ballistic showers, ash and steam emissions, \\
Sept. 1996- & spatter-fed flows, lahars entered north flank drainages, regional ash & \\
Jan. 1997 & fall as far as King Cove (30 mi southwest), Nelson Lagoon (50 mi & \\
& northeast), and Sand Point (60 mi southeast) & \\
& &
\end{tabular}

area around the Emmons Lake volcanic center is uninhabited, only the occasional visitor is at risk from the various proximal hazards. Distal hazards pose less risk to people because time for warning and evacuation is usually adequate. This group of hazards affects people and structures that are more than about five to ten kilometers from the active vent. Volcanic ash, either in explosive eruption columns or ash clouds that drift far away from the volcano, can be both a proximal and a distal hazard, especially to aircraft. Fallout of volcanic ash also can be a proximal and a distal hazard. The geologic map of the Emmons Lake volcanic center (fig. 8) shows deposits and features formed by various volcanic phenomena. The processes that produced these deposits and features are usually confined to the flanks of the volcano and the major drainages that extend from the caldera complex. Only volcanic-ash clouds, ash fallout, pyroclastic flows and surges, and unusually large volume lahars are likely to affect areas more than a few kilometers from the eruptive vent.

\section{Volcanic Hazards}

\section{Volcanic-ash Clouds}

During several of its explosive historical eruptions, Pavlof Volcano has produced ash clouds that drifted considerable distances from the volcano (table 1). Explosive eruptive activity produces fine ash particles that are lofted into the atmosphere forming an eruption cloud (fig. 11) that drifts away from the volcano with the wind. The fine ash particles may remain in the atmosphere for days to weeks depending on the size of the eruption. Volcanic-ash clouds are a potential hazard to all aircraft downwind from the volcano (Miller and Casadevall, 2000).

Pavlof Volcano's eruptions historically were Strombolian eruptions without significant volumes of fine ash. Most of the tephra fallout is local, within a few tens of kilometers of the volcano, especially on areas to the northeast, east, and southeast. The flanking slopes of Pavlof and nearby Pavlof Sister volcanoes are mantled with thick deposits of lapilli tephra from historical eruptions of Pavlof. During the 1996-97 eruption of Pavlof Volcano, diffuse, elongated ash clouds were detected in satellite images. The ash clouds were rarely more than $6 \mathrm{~km}$ above sea level and extended tens to several hundred kilometers beyond the volcano. On November 4, 1996, satellite images showed an ash plume extending $350 \mathrm{~km}$ northeast of the volcano. This was the largest plume produced during the 1996-97 eruption.

Eruptions at any of the known cinder cones within the Emmons Lake volcanic center may produce small amounts of ash. Although no known historical eruptions have occurred from the cinder cones, the morphology and unvegetated flanking slopes of the cones and associated lava flows indicate some activity within the past 500 years. Ash plumes from these vents are not likely to rise more than a few hundred meters to a kilometer above the cone summit and would pose little hazard to aircraft. However, tephra fallout could pose a hazard to someone in the vicinity of the cone during an eruption.

Eruptions could produce volcanic ash clouds at the other stratovolcanoes within the Emmons Lake volcanic center, including Mount Emmons, Mount Hague, Double Crater, Little Pavlof, and Pavlof Sister. These volcanoes have not erupted historically and although they could erupt again, it is not likely that ash clouds from these volcanoes will be any more voluminous than those produced by Pavlof Volcano.

\section{Volcanic-ash Fallout}

Volcanic ash is one of the most disruptive and hazardous products of explosive volcanism. Wind carries volcanic ash clouds produced during explosive eruptions away from the volcano, and if the ash concentration in the plume is great enough, a steady rain or fallout of ash are common. Volcanic ash may be transported long distances in the atmosphere and has the potential to affect areas many hundreds of kilo- 
Table 2. Major hazards from eruptions of the Emmons Lake volcanic center.

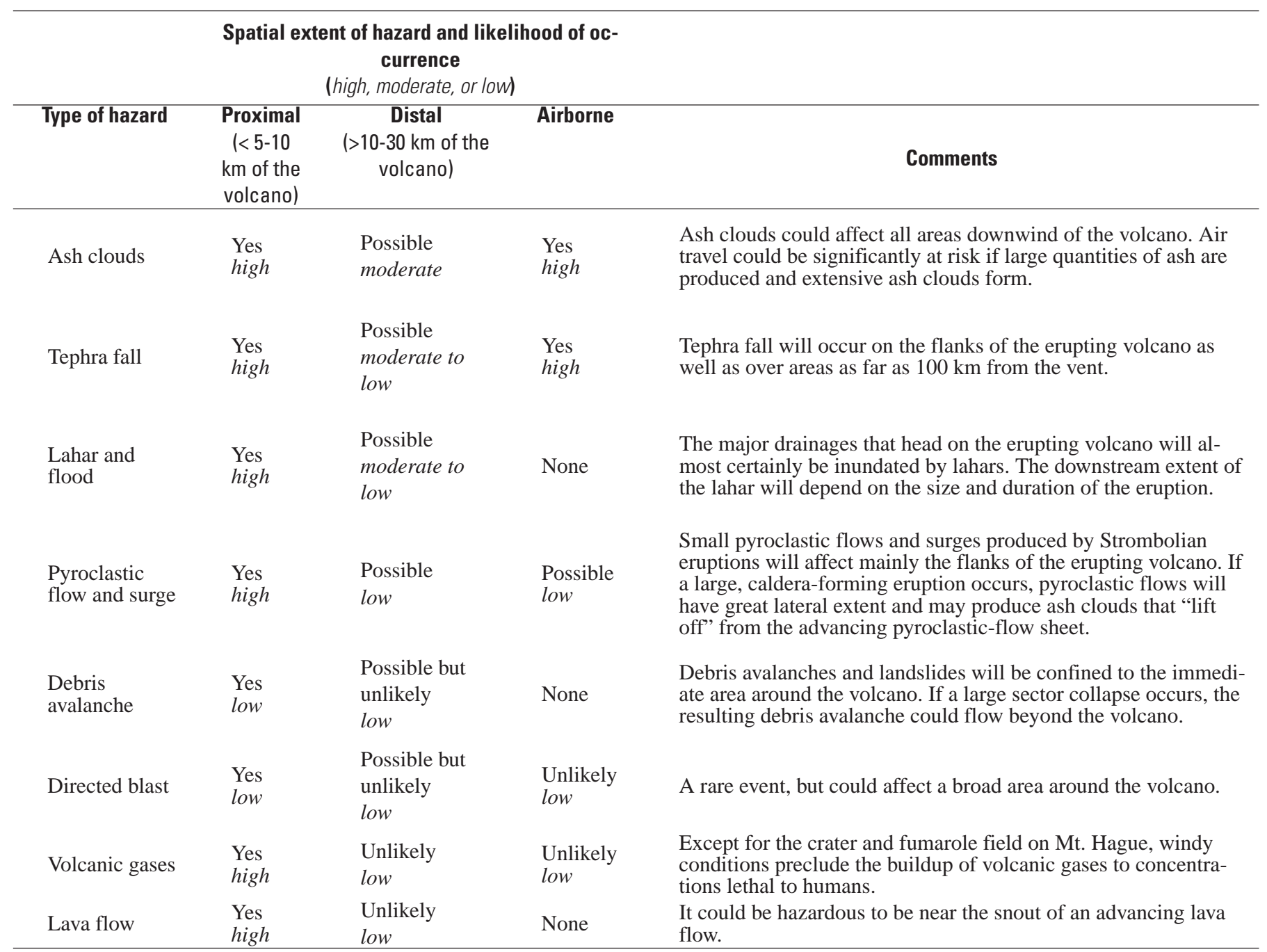

meters from the volcano. Although few people have been killed directly by falling ash, inhaling fine ash particles poses a health hazard that can be life threatening to people with respiratory problems. The weight of a thick ash fall could also cause structures to collapse injuring or killing people. Sometimes a "mud rain" results if airborne volcanic ash mixes with falling rain or snow.

Because few people live near the Emmons Lake volcanic center, the extent of ash fall from historical eruptions is not well known. However, people living on Unga Island, about $95 \mathrm{~km}$ southeast of Pavlof Volcano, have reported light ash fall from Pavlof Volcano as early as 1846, and again in 1914 (McNutt, 1987). Reports from Sand Point, just east of Unga Island, noted light ash fall on September 9, 1976. Communities around the Emmons lake volcanic center (King Cove, Nelson Lagoon, Cold Bay, Sand Point; fig. 12) received small amounts of ash fall from Pavlof during at least one of its historical eruptions.

Large caldera-forming eruptions from the Emmons Lake volcanic center would produce substantial quantities of ash that could fall on areas well beyond those shown on figure 12 .
However, such eruptions are rare, happening on timescales of tens of thousands to hundreds of thousands of years or more. Deposits of volcanic ash discovered near Dawson, Yukon Territory, Canada (fig. 13) have been correlated to the youngest caldera forming eruption at the Emmons Lake volcanic center about 26,000 years ago (Mangan and others, 2003). This indicates that ash dispersal and fallout extended over much of Alaska and into western Canada during the eruption. These large but rare eruptions at the Emmons Lake volcanic center will produce voluminous ash clouds that could blanket Alaska and parts of western Canada with measurable quantities ( $>1 \mathrm{~cm}$ thick) of ash.

Ash fall from future eruptions of other volcanoes within the Emmons Lake volcanic center is not likely to be any more extensive than that associated with historical eruptions of Pavlof Volcano. Thus, the fallout zone noted on figure 13 generally applies to eruptions from all the stratocones within the Emmons Lake volcanic center.

Wind direction and speed control ash plume movement. The areas most likely to receive ash fall are those in the zone downwind of the prevailing winds (fig. 13). Wind data col- 


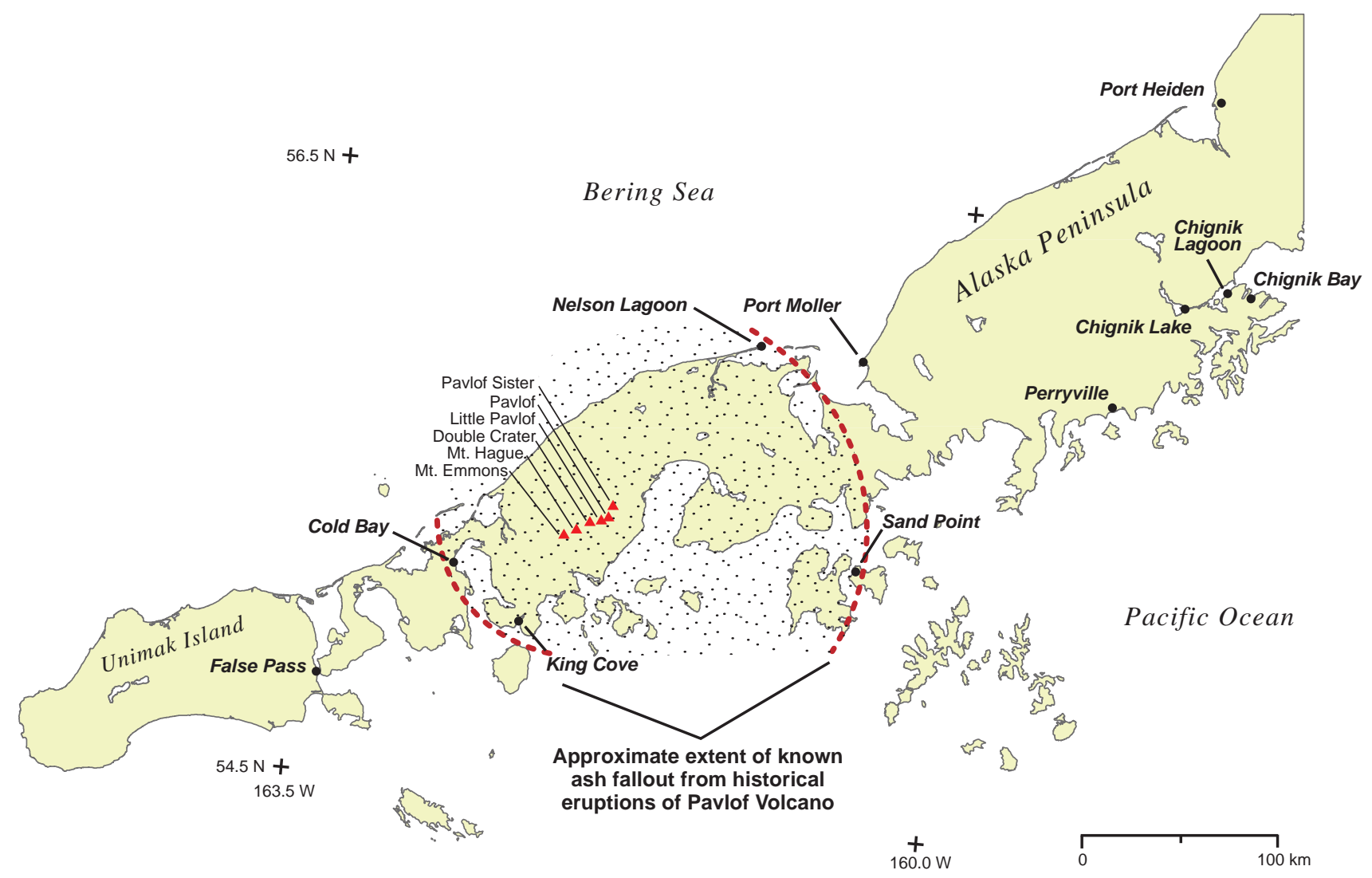

Figure 12. Map showing extent of tephra fallout from historical eruptions of Pavlof Volcano.

lected at Cold Bay since the early 1970s points to the strongest and most consistent winds coming from the west and northwest. Thus, areas east to southeast of the erupting vent would most likely receive ash fall, although historical eruptions of Pavlof Volcano generated ash fall reports in areas west of the volcano, such as Cold Bay. During typical Pavlof eruptions, areas within about $60-100 \mathrm{~km}$ of the volcano (fig. 13) could receive small amounts of ash, but amounts are not likely to exceed a few millimeters. Longer distance transport of ash would depend on the volume of ash erupted, the height of the ash column, and the wind speed above and downwind of the volcano. Large sustained eruptions and high winds could result in transport and fallout of ash over several hundreds of kilometers-wind speeds exceeding 22 meters per second (50 miles per hour) are not uncommon in the region.

Ash accumulation on the ground usually decreases in a downwind direction. How much ash would be produced during an individual future eruption is difficult to predict, and any amount of ash fall on communities and villages could be disruptive and a potential health hazard. Ash fall could affect equipment and facilities in the region, such as power and water purification plants, seafood processing plants, some boats, and electronic equipment.

Blocks and bombs of volcanic-rock debris may be ejected as ballistic projectiles during explosive eruptions, especially those involving water. Usually, ballistic fallout occurs in areas near the vent, but in extreme cases, bombs may be ejected distances of 10 to more than 30 kilometers from the vent. Once the ballistic particles leave the vent, they often follow a parabolic trajectory and may reach heights of roughly 1500 meters above the vent at the apex of their trajectory. At the vent, the ballistic particles have velocities in the range of 150 to 840 meters per second (Waitt and others, 1995). For comparison, the velocity of a bullet leaving the muzzle of a typical firearm is in the range of 300-400 meters per second. Typically, the zone of ballistic fallout is within a few kilometers of the vent and people or low-flying aircraft would be at risk only within this zone. The Pavlof vent ejected ballistic particles during several of its historical eruptions, and volcanic bombs are common on the flanks of the young cinder cones in the region.

\section{Lahars, Lahar-Runout Flows, and Floods}

Many volcanoes in Alaska support large glaciers and perennial snow fields or are covered in snow most of the year. During most eruptions, hot pyroclastic debris of various types is expelled from the volcano and interacts dynamically with the snow and ice on the volcano causing rapid and extensive melting and water production. As melt water mixes with available unconsolidated volcanic debris, various types of flowage phenomena may occur on the volcano flanks and in 

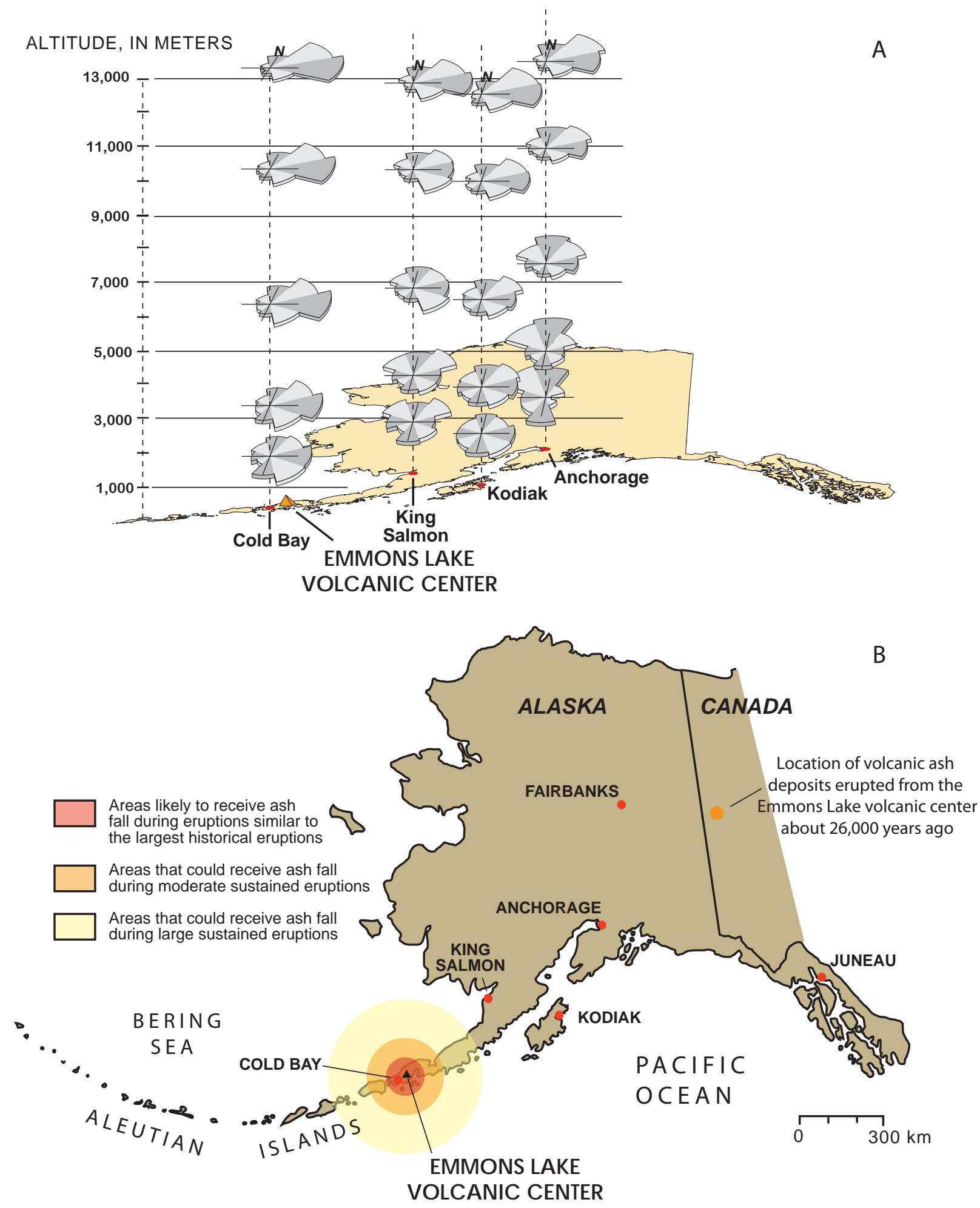

Figure 13a. Prevailing-wind directions for southwestern and south-central Alaska. The length of each windrose sector is proportional to wind frequency as determined by annual percent. Wind data from National Climatic Data Center, National Oceanic and Atmospheric Administration.
Figure 13b. Areas most likely to receive ash fallout from eruptions of the Emmons Lake volcanic center. The specific area of tephra fallout will depend on wind direction and speed. 


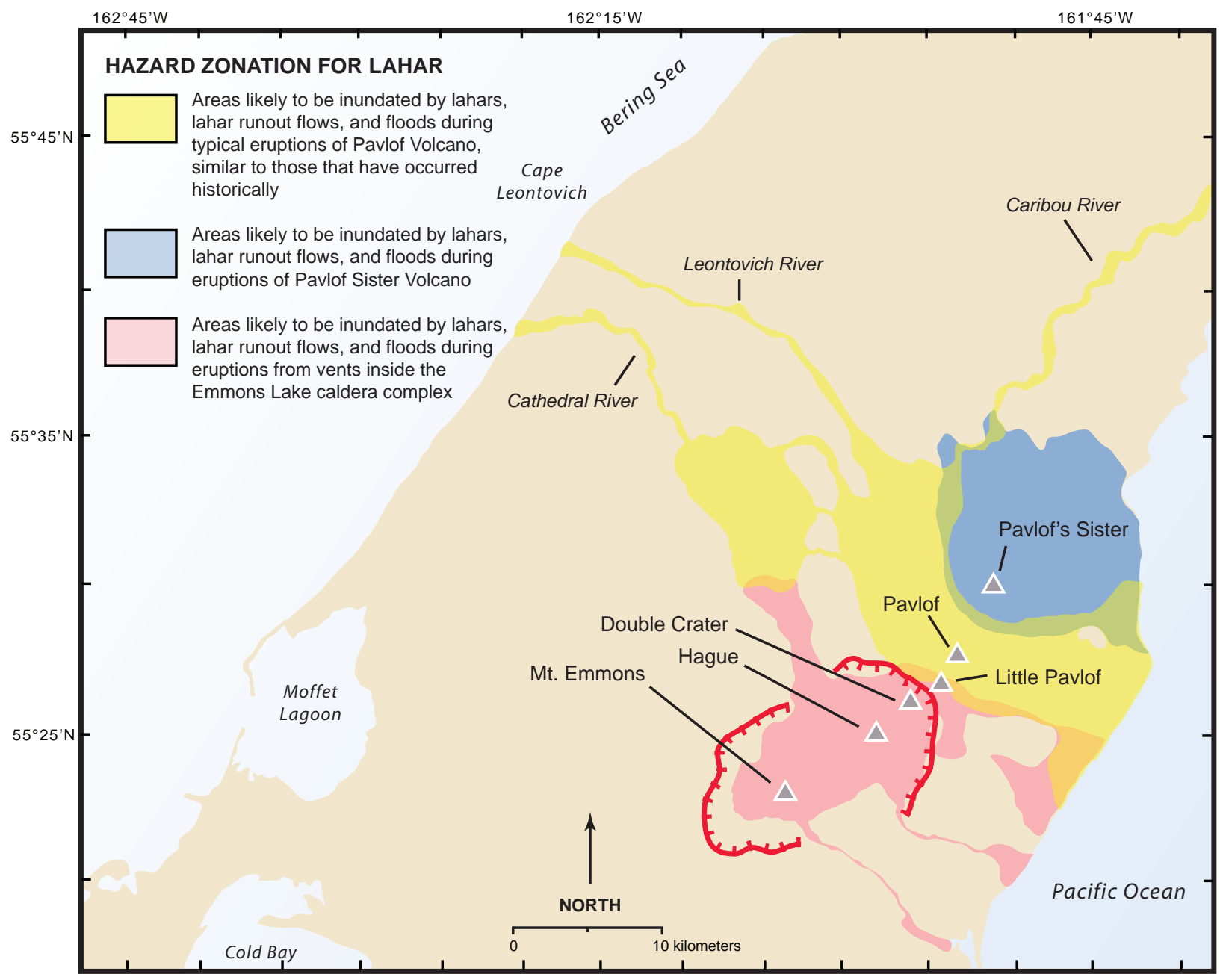

Figure 14. Areas likely to be inundated by lahars, lahar runout flows, and floods.

stream channels and drainages downstream from the volcano. Most of the flow phenomena are categorized as debris flows (fig. 11) or more specifically as clay-poor or noncohesive lahars. Lahars consist of a poorly sorted mixture of boulders, sand, silt, and water that has the consistency of wet concrete. As lahars flow downstream, they typically transform to finer grained, watery flows, called hyperconcentrated flows or lahar-runout flows. If enough sediment is lost from a lahar during flowage, the lahar may transform to a sediment laden streamflow or flood and consist mostly of water.

Lahars may form from water-saturated, clay-rich, volcanic-rock avalanches (Hoblitt and others, 1995; Vallance and Scott, 1997; Vallance, 1999). Such lahars are called clay-rich or cohesive lahars because the matrix sediment of typical deposits contains more than about 3 percent clay of hydrothermal origin. Lahars of this type have not been found within the Emmons Lake volcanic center.

Noncohesive lahar deposits of Holocene age have been identified along the major drainages that head on Pavlof and Pavlof Sister. The Leontovich, Caribou, and Cathedral Rivers, for example, were inundated by lahars during several of Pavlof's historical eruptions and some of these lahars flowed as far as the Bering Sea and the Pacific Ocean (fig. 14). The lahar deposits consist of accumulations of dark grey, sandy fine gravel, coarse sand, and boulders several meters thick. They form prominent terraces and valley fill deposits on the lower flanks of Pavlof Volcano (fig. 15) and in the upper reaches of the Caribou and Leontovich Rivers. In other areas, lahar inundation has resulted in broad, low-relief lahar fans common on the flanks of Pavlof Sister, the south flank of Pavlof, and in the upper Cathedral River drainage.

Lahars are most often formed during eruptions of Pavlof Volcano when hot pyroclastic debris falls or flows onto the snow and glacier ice that mantles the flanks of the volcano. Debris-covered lobes of stagnant glacier ice on the north flank of Pavlof have been persistent sources of water and sediment for lahar generation during eruptions. Although the total volume of glacier ice on Pavlof Volcano is unknown, approximately $2 \mathrm{~km}^{3}$ of debris-covered glacier ice is present within the runout zone of lava and pyroclastic flows typically generated during Pavlof eruptions. Thus, during future eruptions of Pavlof, lahars are likely to form, and the flows could inundate areas on the flanks of the volcano as well as any of the drainages that head on the volcano (fig. 14). 


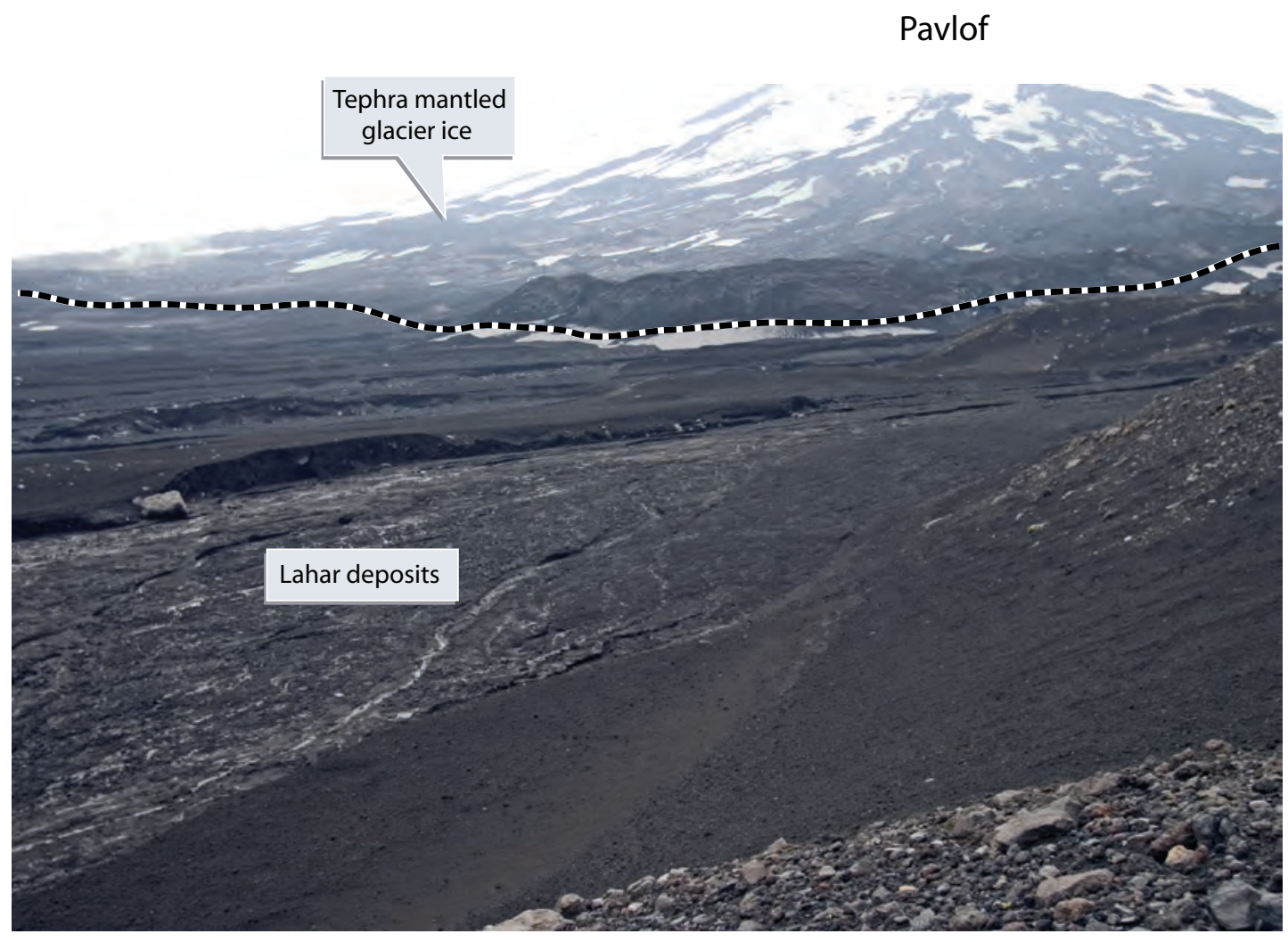

Figure 15. Photograph of lahar deposits produced by historical eruptions of Pavlof Volcano. Photograph by C.F. Waythomas, August 2005.

Lahars may also form during eruptions of Pavlof Sister, or during eruptions at any of the stratocones and vents within the Emmons Lake caldera complex. Although it is less likely that lahar-producing eruptions will occur at these volcanic vents, the extensive ice and snow cover inside the caldera and on Pavlof Sister volcano suggests that lahars could form and fill low-lying areas and drainages (fig. 14).

Lahars, lahar-runout flows, and floods generated by eruptions within the Emmons Lake volcanic center can move rapidly and are likely to have flow depths of several meters. The lahar flows can transport significant amounts of sediment as well as boulder- and block-size particles, which may be hot. These flows would probably destroy vegetation and habitat along the flow path and would be hazardous to people or property they encounter. The high frequency of eruptions of Pavlof Volcano indicates that lahars will form during future eruptions. Planned developments in the major river valleys, especially the Leontovich, Caribou, and Cathedral River valleys, could be at risk from lahars, lahar-runout flows, and floods. At this time, lahars pose only a minor hazard because few people visit the area and there are no permanent structures or facilities.

\section{Debris Avalanche}

Large volcanic landslides, also known as flank collapse, or sector collapse (fig. 11), typically form because of a struc- tural weakness in the upper part of the volcano. If a collapse occurs, a debris avalanche evolves from the failed rock mass and moves rapidly down the volcano flank. A typical debris avalanche forms a bouldery, unsorted gravel deposit many kilometers from its source with a characteristic hummocky surface and broad areal extent. Most debris-avalanche deposits are traceable up the slopes of the volcano to an arcuate- or horseshoe-shaped scar at or near the volcano summit that marks the zone of collapse and origin of the avalanche. Most large debris avalanches (greater than 1 cubic kilometer) occur during eruptions (Siebert, 1996). However, it is possible for large-scale collapse of a volcanic cone to occur when the volcano is not erupting, sometimes as a result of long-term chemicl alteration of volcanic rock in the edifice by hot, acidic ground water.

Debris-avalanche deposits and evidence for flank collapse have not been recognized at any of the stratocones and vents in the Emmons Lake volcanic center. Small collapse scars are present on the northwest flank of Pavlof Sister volcano (fig. 16), but these are the only known features that may be related to flank collapse.

The debris-avalanche hazard zone at the Emmons Lake volcanic center and the maximum likely runout distance of a future debris avalanche was estimated using the ratio of the fall height $(\mathrm{H})$ to runout distance $(\mathrm{L})$ of known avalanche deposits from various sources. Hazard boundaries were esti- 


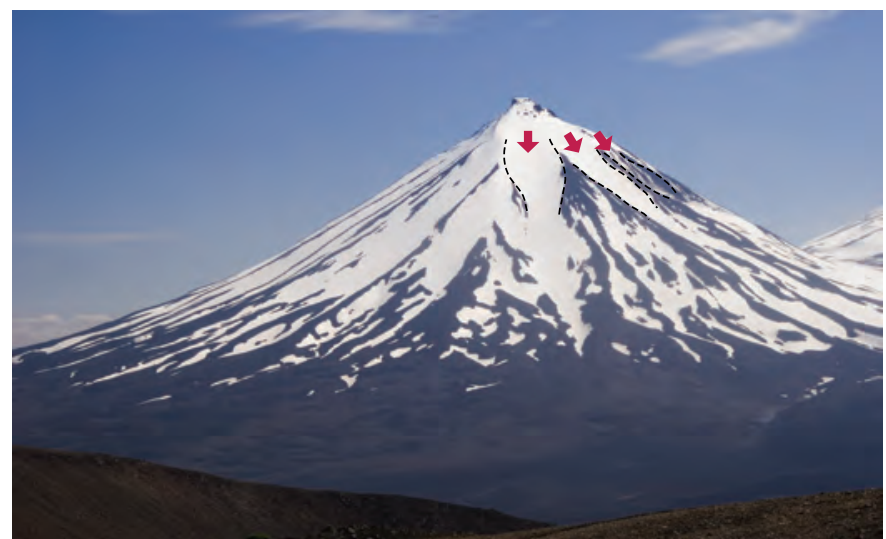

Figure 16. Photograph of the north flank of Pavlof Sister volcano showing possible debris-avalanche scars. Photograph by C.F. Waythomas, August 2005. mated by using H/L values of 0.2 and 0.15 for Pavlof Volcano (fig. 17) and 0.2 for Mount Emmons, Hague, Little Pavlof, and Pavlof Sister (fig. 18). To determine L, divide H (summit altitude of each stratocone) by the $\mathrm{H} / \mathrm{L}$ ratio to give the approximate runout extent for debris avalanches with volumes of about $0.5 \mathrm{~km}^{3}$ and larger. It is difficult to know if future debris avalanches are likely to form since debris-avalanche deposits have not been found in the geologic record of the Emmons Lake volcanic center. None of the major stratocones in the center show any obvious signs of instability and significant hydrothermal alteration, often a sign of potential rock weakness, is uncommon. A major collapse of the Pavlof or Pavlof Sister cones is unlikely unless a very large amount of magma begins rising through the crust toward the surface. Thus, the hazard from debris avalanche is minor unless conditions at the volcano change significantly.

A large flank collapse and debris avalanche on the southeast flank of Pavlof Volcano could introduce rocky debris into Pavlof Bay, possibly causing small local waves in the bay.

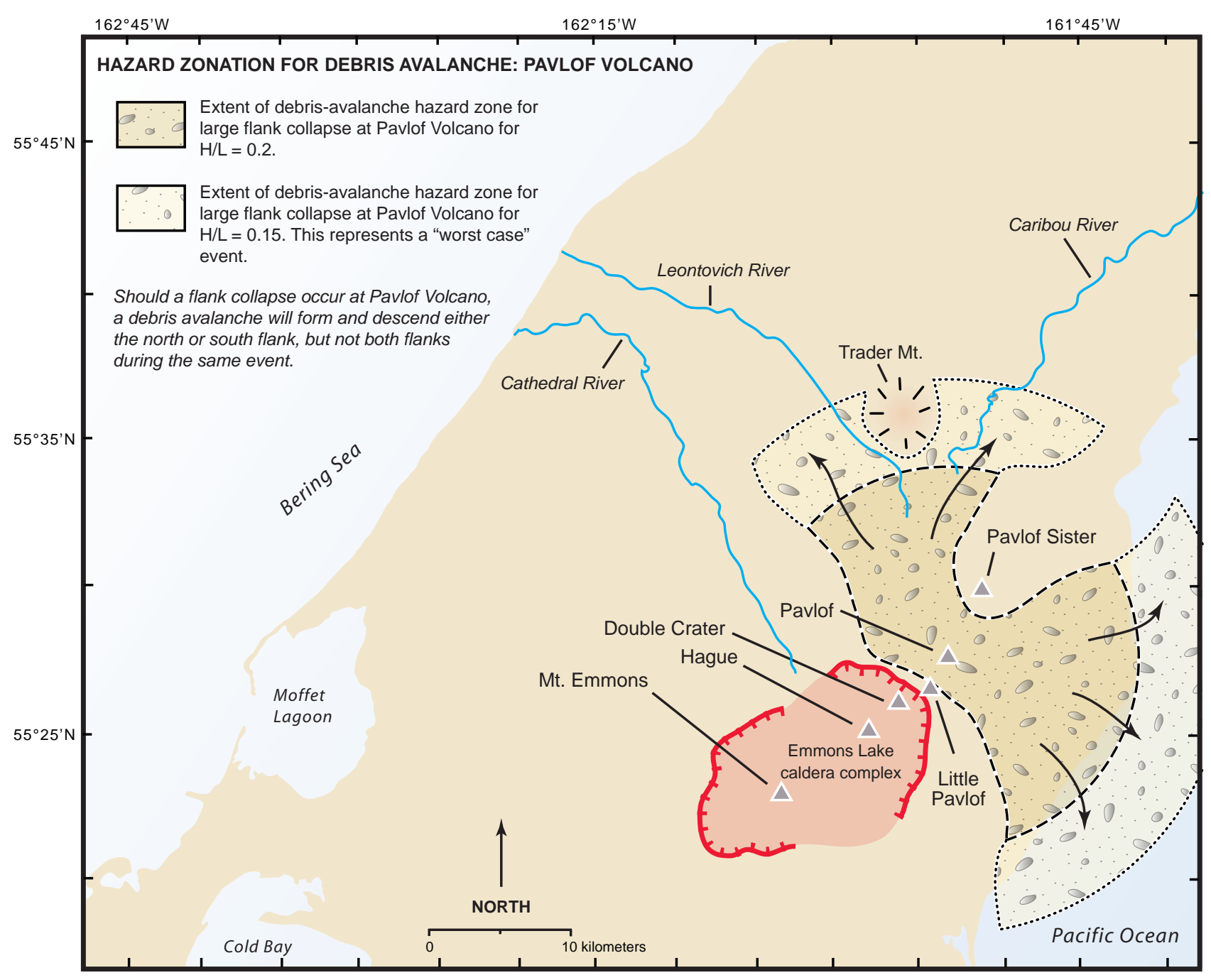

Figure 17. Extent of debris-avalanche hazard zone for Pavlof Volcano. 


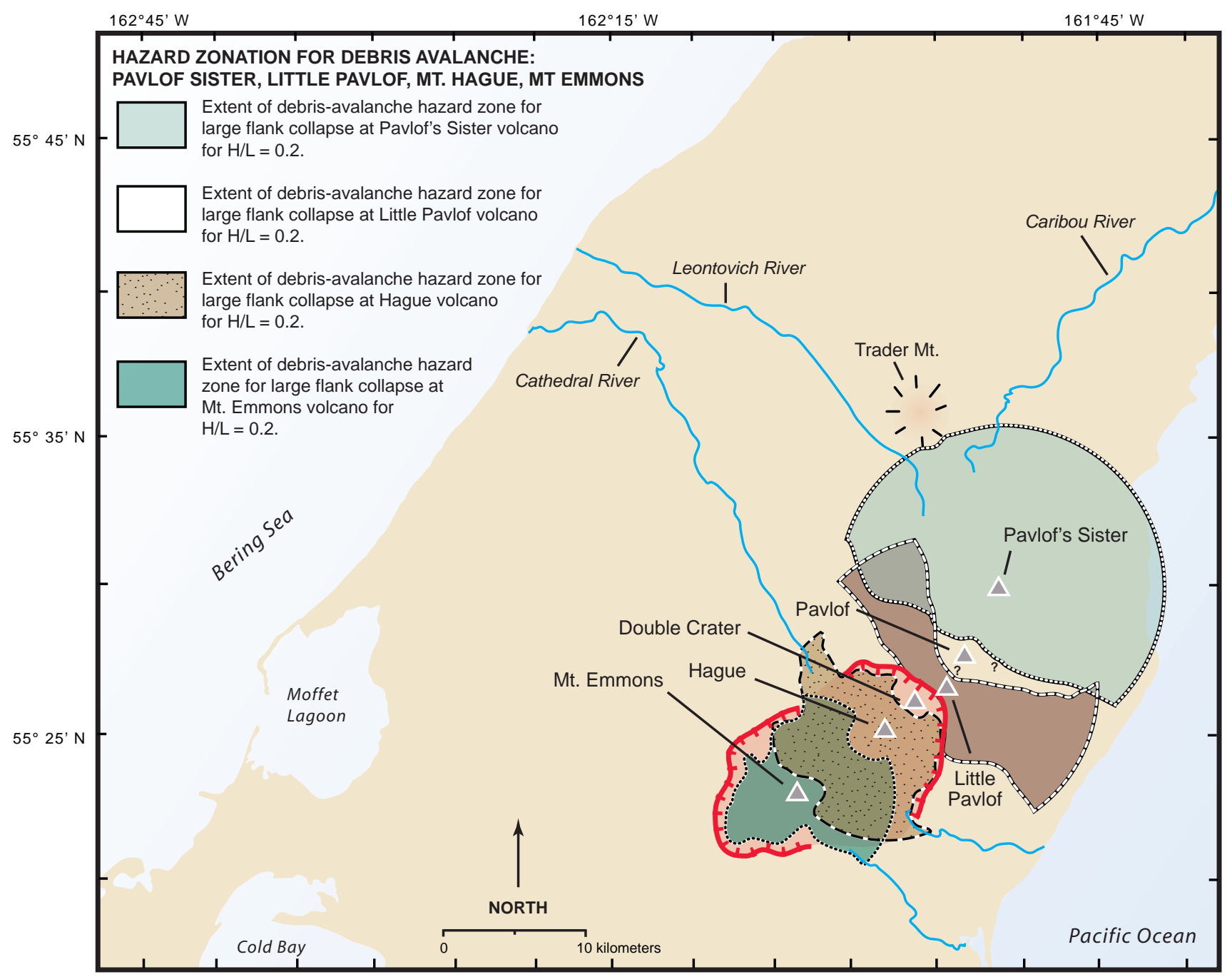

Figure 18. Extent of debris-avalanche hazard zone for Pavlof Sister, Little Pavlof, Hague, and Mount Emmons volcanoes.

The water along the west side of Pavlof Bay is shallow, and it is unlikely that a debris avalanche would flow very far into the bay. Thus, the probability of a debris-avalanche-induced tsunami in Pavlof Bay associated with a large flank collapse of Pavlof is very low.

\section{Pyroclastic Flows and Surges}

A pyroclastic flow is a hot, dry mixture of volcanic-rock debris and gas that flows rapidly downslope away from its volcanic source. The path of a pyroclastic flow may be controlled by the underlying topography and the flows tend to follow valleys and river drainages, although they may surmount topographic obstacles if they have sufficient volume. A pyroclastic surge is similar to and often occurs with a pyroclastic flow but has higher gas content. Because it is mostly gas, a pyroclastic surge moves more rapidly than a pyroclastic flow and may not be confined by topography, and therefore, may climb up and over ridges. Any of the major drainages within the Emmons
Lake volcanic center could be engulfed by pyroclastic flows even during modest eruptions. Because they are hot (several hundred degrees Celsius) and fast moving, both pyroclastic flows and surges could be lethal to anyone within a few kilometers of an erupting vent.

Several types of pyroclastic flows have been generated by eruptions at the Emmons Lake volcanic center. During the voluminous, caldera-forming eruptions at Emmons Lake caldera, large-volume, silica-rich pyroclastic flows spilled over the caldera rim and invaded valleys and lowland areas. These flows extended to the modern coastline and beyond (fig. 19) and record extreme and very hazardous explosive eruptions. In several areas, the pyroclastic deposits filled valleys and were sufficiently thick and hot to weld in place, or weld after secondary flowage downslope. Welded-pyroclastic-flow deposits are rare in the Aleutian arc of Alaska and signal very high temperature emplacement and ponding of deposits in low-lying areas. The most recent large, caldera-forming eruption occurred about 26,000 years ago from a vent inside the 
Emmons Lake caldera complex (Mangan and others, 2003). This eruption produced non-welded, pumice-rich, pyroclastic flows that extended as far as $60 \mathrm{~km}$ from the caldera complex. Deposits from this eruption are found on all sides of the caldera complex and are up to $12 \mathrm{~m}$ thick where exposed in sea cliffs along the Bering Sea coastline (fig. 20). A future eruption capable of producing similar pyroclastic deposits would be a major, catastrophic event, and areas within 50 to $100 \mathrm{~km}$ of the vent would be completely engulfed by the hot, fast-moving flows (fig. 19). The towns of Cold Bay and King Cove could be at risk from an eruption of this magnitude.

However, the frequency of occurrence of eruptions this size at the Emmons Lake volcanic center is low, perhaps every 60,000 to 100,000 years.

The most recent historical eruptions of Pavlof Volcano in 1986 and 1996 produced small pyroclastic scoria flows that descended both the north and south flanks of the volcano, flowing approximately $5-10 \mathrm{~km}$ from the vent. These pyroclastic flows were produced when piles of agglutinate and spatter that accumulated on the rim of the vent collapsed and released hot gas and ash trapped within. The flows were able to scour snow and ice on the lower flanks of the volcano leading to the generation of lahars and floods in the drainages heading on the north flank of Pavlof. Pyroclastic flows produced by collapsing spatter piles are not particularly large, and they are not likely to extend more than about $10-15 \mathrm{~km}$ from the Pavlof summit. Such flows would be highly directional and would sweep only a portion of the particular flank they descend. Thus, they would be hazardous to anyone in the immediate vicinity of the erupting volcano, especially on the flanks or anywhere near the vent.

If Pavlof Volcano, or one of the other stratocones in the caldera, outperforms historical eruptions with larger and more explosive events, it is possible for high vertical columns of ash and pyroclastic debris to be ejected from the vent. If this occurs, pyroclastic flows could develop by collapse of the ash column, forming a rain of pyroclastic debris and tephra that falls back toward the volcano. Pyroclastic flows generated by this process would engulf all sides of the volcano and could flow several tens of kilometers from the source vent (fig. 19). Pyroclastic flow deposits produced by column collapse are only sparsely preserved in the vicinity of the Emmons Lake volcanic center, mainly in the Cathedral and Leontovich River drainages. However, the ca. 26,000-year-old, caldera-forming eruption at Emmons Lake caldera, produced pumiceous, pyroclastic flow deposits. Figure 19 shows the estimated hazard

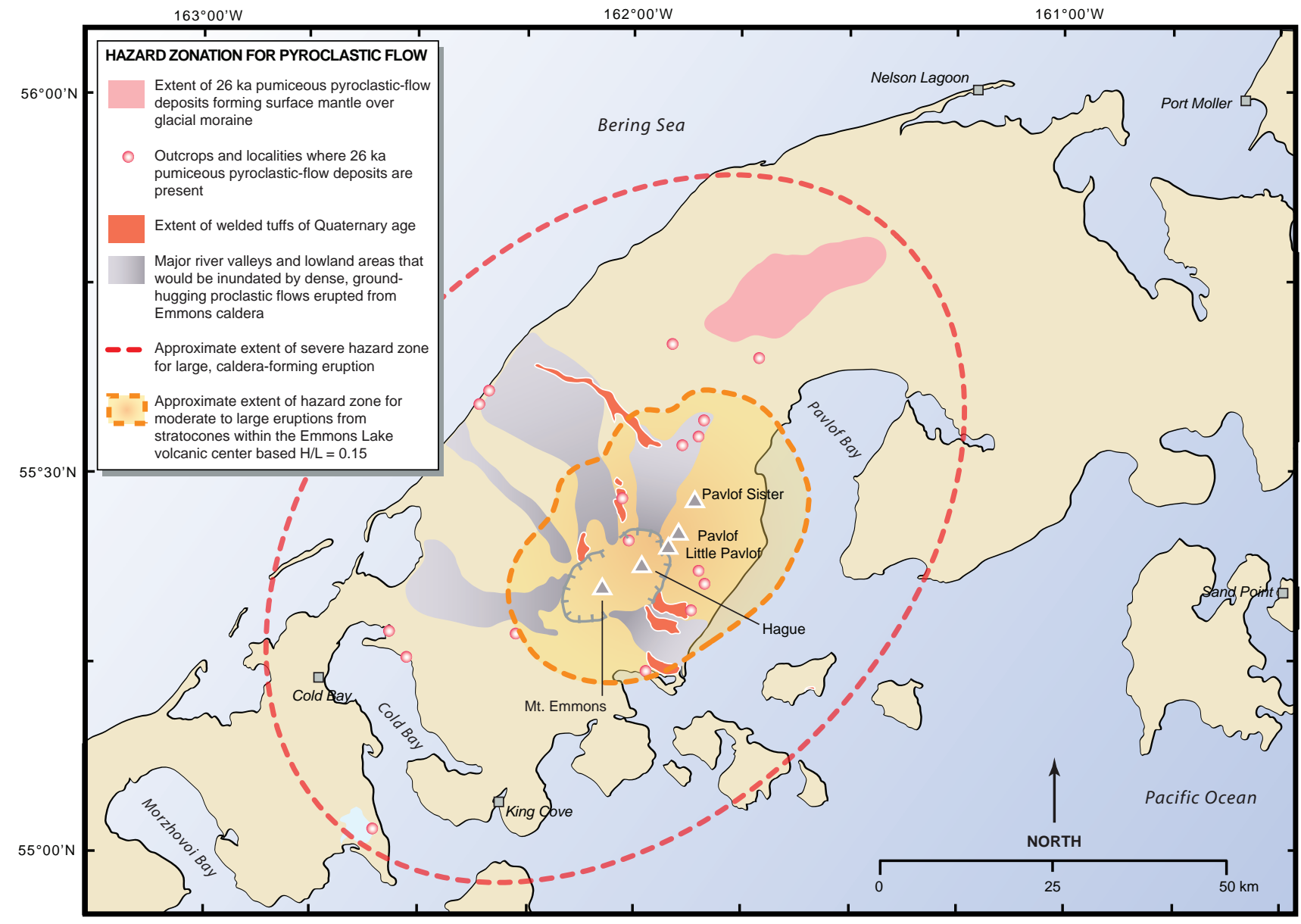

Figure 19. Extent of pyroclastic-flow hazard zone. 


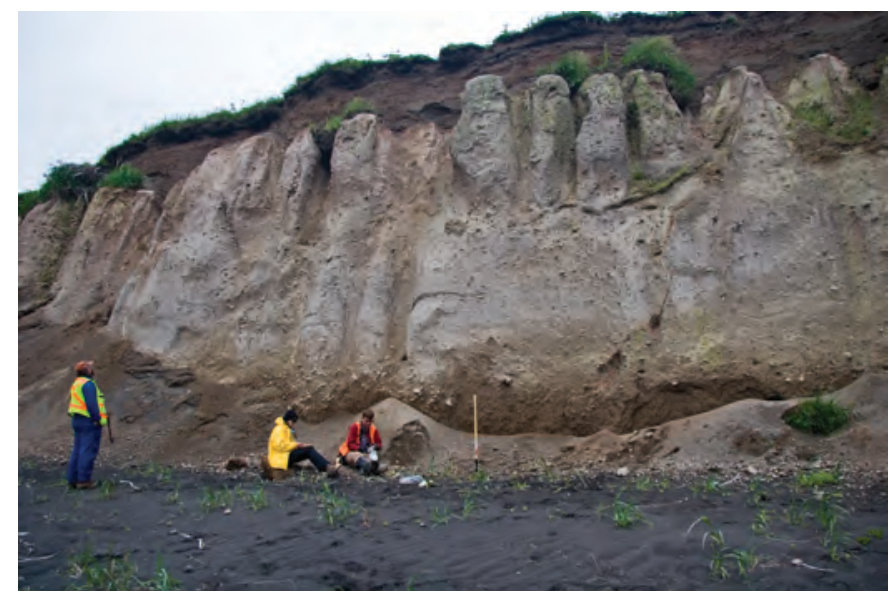

Figure 20. Photograph of pumice-rich, pyroclastic flow deposits exposed along the Bering Sea coast north of the Emmons Lake volcanic center. Photograph by C.F. Waythomas, August 2005. zone for this type of pyroclastic flow and surge using the $\mathrm{H} / \mathrm{L}$ ratio method as described previously, where $\mathrm{H} / \mathrm{L}=0.15$ delineates the hazard zone.

It is difficult to accurately predict the extent of a pyroclastic surge, but because of their genetic relation to pyroclastic flows, they have a slightly greater lateral extent. The location of the hazard boundary for pyroclastic surges is uncertain and is not shown in figure 19 or on plate 1 . The boundary is approximated conservatively by the hazard boundary for pyroclastic flow, although we expect a pyroclastic surge to extend beyond this boundary, perhaps by at least several kilometers. Pyroclastic surges are hot $\left(300\right.$ to $\left.800^{\circ} \mathrm{C}\right)$ and gaseous, and death or injury from asphyxiation and burning is likely. Because the surge cloud may travel very fast (at least tens of meters per second), detach itself from the pyroclastic flow, and surmount topographic barriers, evacuation of the area near the volcano prior to the eruption is the only way to eliminate risk from pyroclastic surges.

\section{Directed Blasts}

A directed blast is a large-scale lateral volcanic explosion caused by a major landslide or slope failure that uncaps

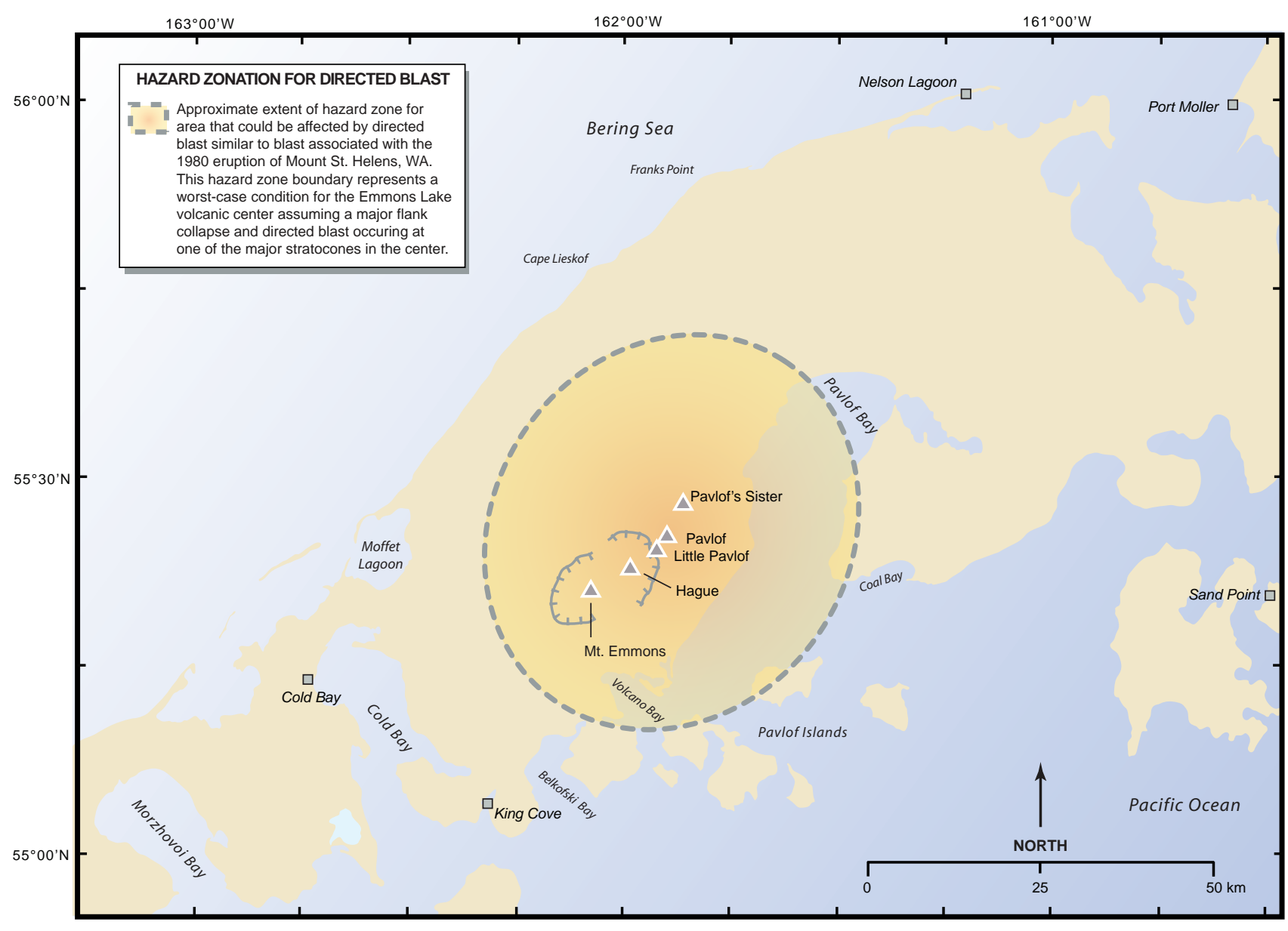

Figure 21. Extent of directed blast hazard zone. 
the internal plumbing system of the volcano. A directed blast is a rare event in the history of a volcano. Geologic studies of the Emmons Lake volcanic center have produced no evidence for major slope failures or directed blasts. The hazard-zone boundary showing the area most likely to be affected by a directed blast (fig. 21) is based on data from the 1980 eruption of Mount St. Helens. The directed blast associated with that eruption is one of the largest known historical events and thus is assumed to be a "worst case" example. If a directed blast were to occur at one of the stratocones within the Emmons Lake volcanic center, it could affect a broad area, possibly a $180^{\circ}$ sector from the vent. A directed blast usually happens in the first few minutes of an eruption and leaves no time for warning or evacuation once the eruption is imminent. Living things in the path of a directed blast would be killed or destroyed by impact, burning, abrasion, burial, and heat.

\section{Lava Flows}

Streams of flowing molten rock or lava will almost certainly form during future eruptions inside the Emmons Lake volcanic center. Most of the caldera floor and the southern breach of the caldera are mantled by blocky aa lava flows of Holocene age (fig. 22) erupted from one of several vents inside the caldera (fig. 8). Lava flows commonly develop after explosive activity at the volcano declines, but are the principal product of dominantly effusive eruptions. Several of the cinder cones within Emmons Lake caldera have produced lava flows; some extend almost to the shore of Pavlof Bay south of the caldera (fig. 8). The composition of the lava flows ranges from basalt to andesite and most of the flows have jagged, blocky, surfaces. Future eruptions from vents within the caldera would likely generate lava flows similar to those preserved on the caldera floor. Such lava flows are likely to move slowly downslope, probably not more than a few tens of meters per hour. Lava flows of this type pose little hazard to people who could easily walk away from them. Some of these flows could develop steep, unstable fronts and could shed hot blocks, debris, and possibly gas downslope ahead of the advancing lava flow. This could be hazardous to anyone near the flow front. Lava flows that reach snow and ice could generate localized flooding and may initiate minor steam explosions. It is also possible for lava flows originating from vents inside the caldera to block stream channels and rivers, creating temporary dams. Should these lava dams breach and fail, downstream flooding would occur.

Strombolian eruptions at Pavlof Volcano have produced thick piles of agglutinate and spatter on or near the rim of the erupting vent. Occasionally these accumulations of spatter and agglutinate begin to flow under the influence of gravity and form clast-rich, or spatter-fed lava flows. These flows typically do not extend very far from their source vent, perhaps a kilometer or two, and are not hazardous unless someone is actually close to the flow as it is being emplaced. It is possible for the spatter-fed flows to contain small amounts of gas that could lead to the formation of small pyroclastic flows if released rapidly.

The hazard zone for lava flows is based on the extent of lava flows generated by effusive eruptions from vents inside Emmons Lake caldera and the approximate extent of spatterfed flows on Pavlof Volcano associated with historical eruptive activity (fig. 23).

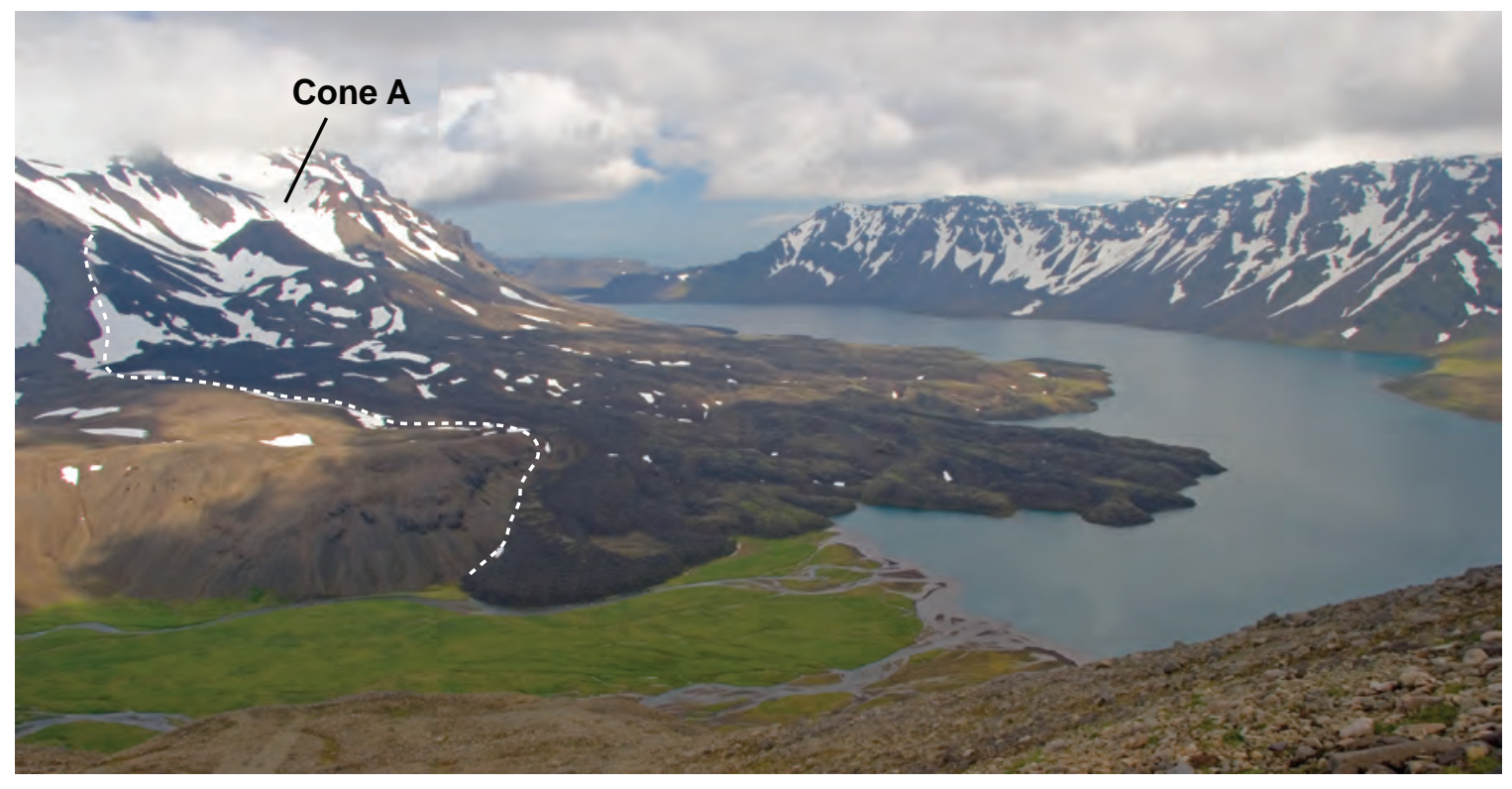

Figure 22. Photograph of lava flows of Holocene age erupted from Cone $A$ and terminating in Emmons Lake. View is to the south. Photograph by C.F. Waythomas, August 2005. 


\section{Volcanic Gases}

Gases are emitted by most active volcanoes. Magma within a volcanic edifice contains dissolved gases and the heat associated with magmatic systems boils off shallow ground water that is often present within a volcano. The most common volcanic gases are water vapor, carbon dioxide, carbon monoxide, sulfur dioxide, and hydrogen sulfide. Volcanic sulfur and halide gases that encounter water can form large amounts of sulfuric acid and minor amounts of hydrochloric acid and hydrofluoric acid as aerosols or droplets. Both carbon monoxide and carbon dioxide are colorless and odorless and thus impossible to detect without a measuring device. Carbon dioxide is heavier than air and may displace the available oxygen in confined spaces or low-lying areas causing suffocation. In high concentrations, carbon dioxide, hydrogen sulfide, and sulfur dioxide may be harmful or toxic to humans and may damage vegetation downwind from the volcano. Acid precipitation may develop from the mixing of snow or rain with acidic volcanic aerosols and may cause various types of skin and respiratory irritations and corrosive damage to materials. Because wind tends to disperse volcanic gas, it is typically not found near the ground in concentrations hazardous to humans or animals more than about 10 kilometers from the volcano. During large eruptions, significant volumes of gas can travel high in the atmosphere downwind from the volcano, persisting for days and extending thousands of kilometers.

Volcanic gases escaping from vents and fumaroles within the Emmons Lake volcanic center (fig. 24) are generally not hazardous because the region experiences windy conditions on a regular basis. The ephemeral crater lake at the summit of Mount Hague and its flank fumaroles (fig. 4) are the most persistently active locations for volcanic gases, and occasionally gas emissions from these locations could be hazardous to someone in the crater or in the vicinity of the fumarole field. Because of the geometry of the Hague crater, gases may become trapped if the air is calm. A whitish steam plume, composed mostly of water vapor, and probably small amounts of carbon dioxide and sulfur dioxide gas, is sometimes appar-

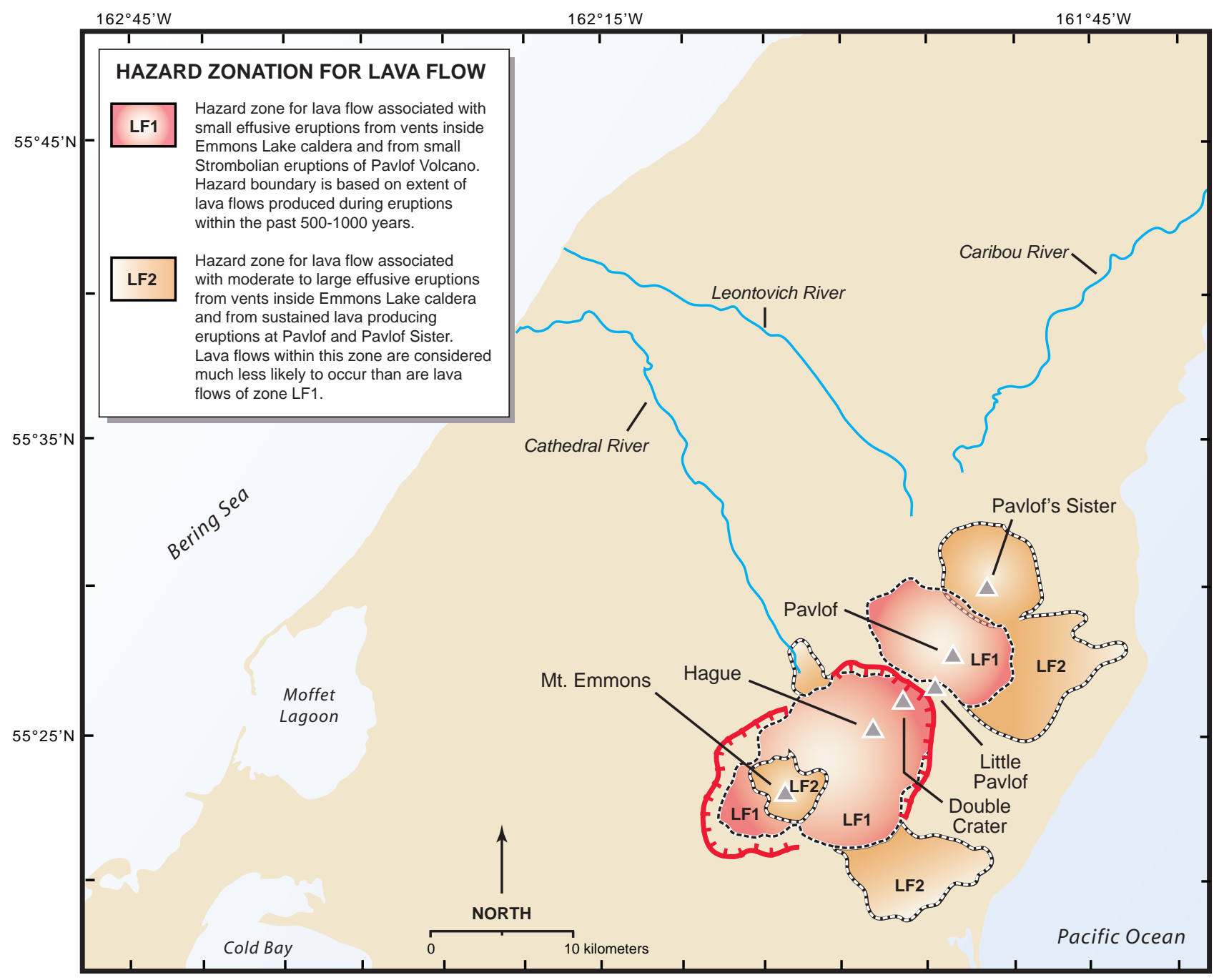

Figure 23. Extent of lava flow hazard zone. 


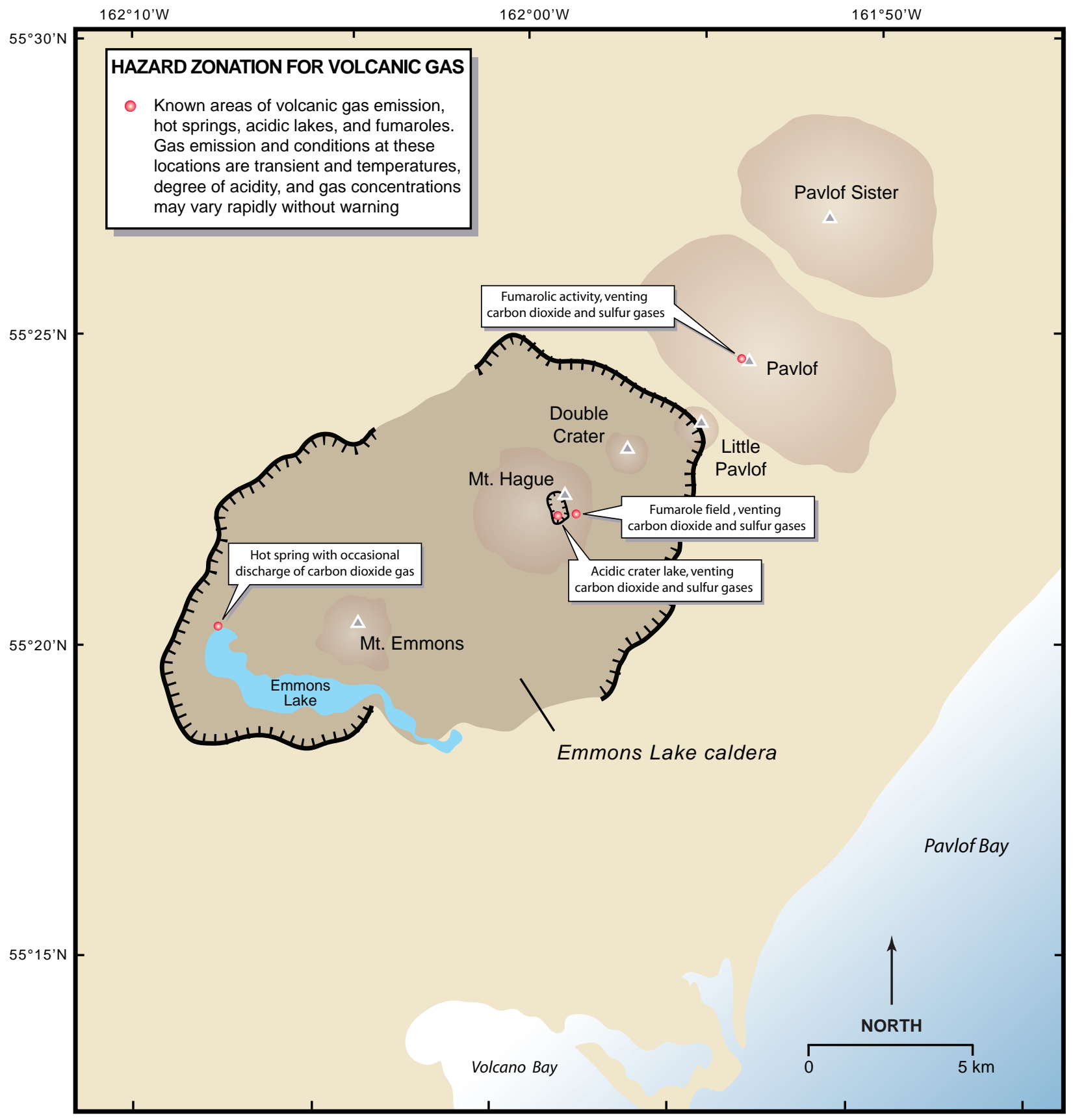

Figure 24. Map showing location of hot springs, fumaroles, and acidic lakes and potential sites for volcanic gas emission.

ent rising from fumaroles on the southeast flank of Mount Hague (fig. 24). The steam plume sometimes appears to be vigorously roiling and has been mistaken for an eruption cloud. Although it has not been possible to sample water from the crater lake at Hague, the $\mathrm{pH}$ of the water is likely very low (acidic), and the water at times may be close to boiling. Entering the lake in the crater, even if it is shallow, could be hazardous.

\section{Event Frequency and Risk}

Future eruptions within the Emmons Lake volcanic center can be expected, but the timing of the next eruption is uncertain and known only qualitatively (table 3). Pavlof Volcano is the most frequently active volcano in Alaska, and has had approximately 37 eruptive events since about 1762, including the most recent eruption in 1996. Thus, Pavlof experiences some degree of eruptive activity about every 6-7 years, and it would not be unusual for activity to resume in the near future. 
A future eruption of Pavlof Volcano is likely to be similar to recent historical eruptions, and would probably involve a summit vent Strombolian eruption accompanied by limited ash production, spatter-fed lava flows, and lahar generation. Ash clouds rising above $7500 \mathrm{~m}$ (25,000 feet) could occur during a Strombolian eruption of Pavlof, but these are likely to be short-lived events without sustained ash production.

Eruptions from other stratocones and vents within the center occur less frequently than at Pavlof Volcano, although the fresh-appearing morphology of several of the intracaldera cinder cones indicates that activity at these locations could happen in the near future. Cinder cone eruptions are not likely to be hazardous, but could result in the production of small volume, low-level ash clouds and intracaldera lava flows. Although Mount Hague has had no known historical eruptions, its morphology, fumarolic activity and ephemeral crater lake suggest that it could produce an eruption in the near future. An eruption at Mount Hague could involve water, and might result in the explosive discharge of rock debris and steam that may or may not lead to a magmatic eruption.

Because of their snow and ice cover, the primary proximal hazards from eruptions of Pavlof and Pavlof Sister would be lahars, lahar-runout flows, and floods, as well as ash fall, ballistic fallout, and pyroclastic flows. Lahars likely would inundate the major drainages, specifically the Caribou, Leontovich, and Cathedral Rivers, as well as smaller drainages originating on the volcanoes' flanks. Thick deposits of volcaniclastic sediment could accumulate in affected valleys and drainages and sediment-laden runoff may persist for months to years after the eruption, causing reduced water quality and stream habitat.

The area in the immediate vicinity of the Emmons Lake volcanic center is uninhabited and no permanent structures or facilities are present. The closest towns and villages are more than 40 kilometers from the volcano and would be affected only by ash fall. Fine ash could fall on Cold Bay, King Cove, Nelson Lagoon, and Sand Point as it has during historical eruptions of Pavlof Volcano. Several millimeters of ash could accumulate in these areas depending on the prevailing winds at the time of the eruption. In the event of a large, rare, explosive eruption, pyroclastic flows could engulf a broad region as far as Cold Bay and King Cove (fig. 19). Should a sustained explosive eruption occur at Pavlof Volcano or at one of the other stratocones in the center, clouds of volcanic ash would be generated that could drift thousands of kilometers downwind. All aircraft, some facilities, and living things - including humans-downwind from the volcano are at some risk from effects of volcanic-ash clouds and ash fallout. Ash clouds could rise to altitudes of 7500 meters or more and move into the flight paths of aircraft using the Cold Bay airport and other local landing areas. Local air routes in the vicinity of the Emmons Lake volcanic center could be blocked by drifting clouds of volcanic ash making access to or from other parts of Alaska difficult or impossible.

Aircraft using air routes over the North Pacific and areas downwind of the Emmons Lake volcanic center (fig. 25) could encounter clouds of volcanic ash for hours to days after a large ash-producing eruption. During an eruption, it is possible that multiple ash clouds will be generated. The frequency at which dangerous clouds of volcanic ash are produced and the amount of ash in the ash cloud cannot be estimated with certainty.

Signs of volcanic unrest, such as elevated levels of earthquake activity, a change in emission rate and volume of volcanic gas, a change in the surface elevation of the volcano, or an increase in ground temperature at or near the vent, usually precede an eruption. If such signs of unrest can be detected early in the eruptive cycle, reasonable estimates of the likelihood of an eruption and the possibilities for sustained ash production can be determined. However, the characteristics of an ash cloud cannot be predicted before an eruption

Table 3. Probability of eruptive activity for main vents in the Emmons Lake volcanic center.

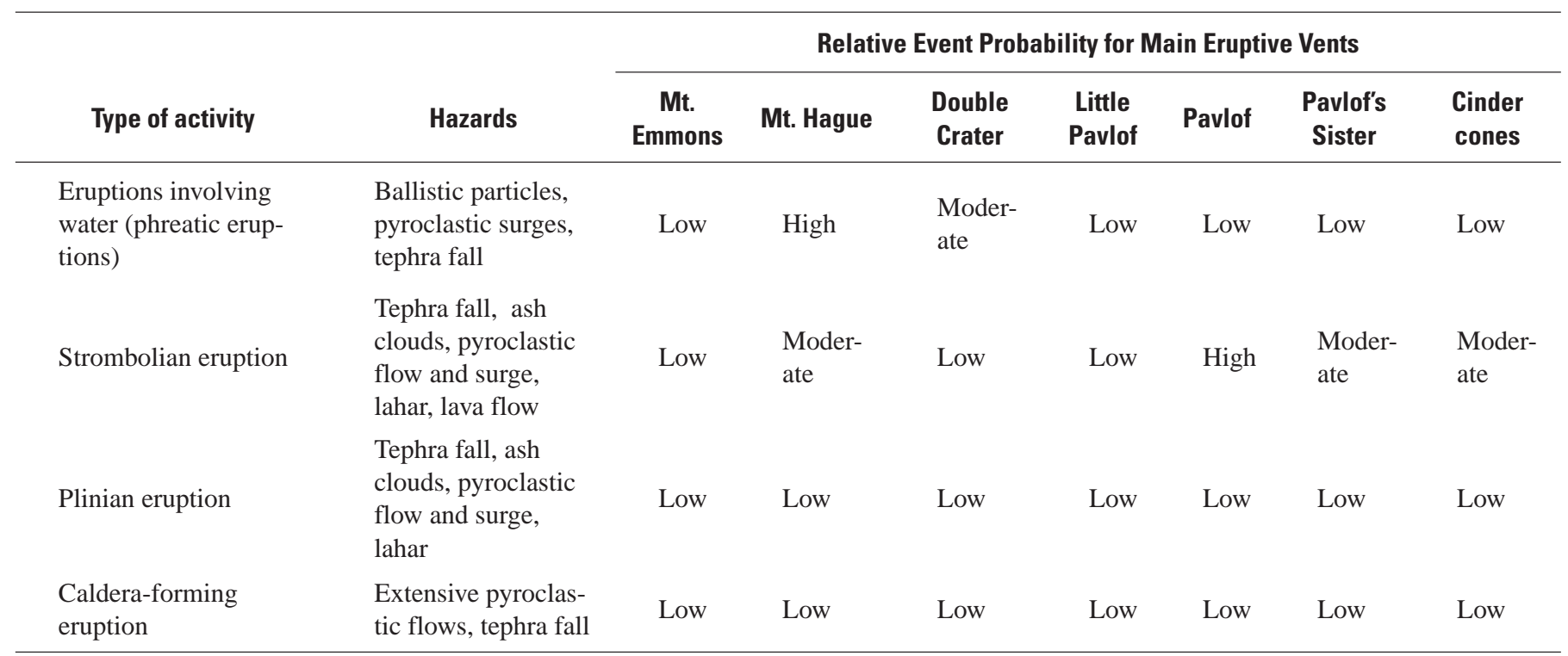




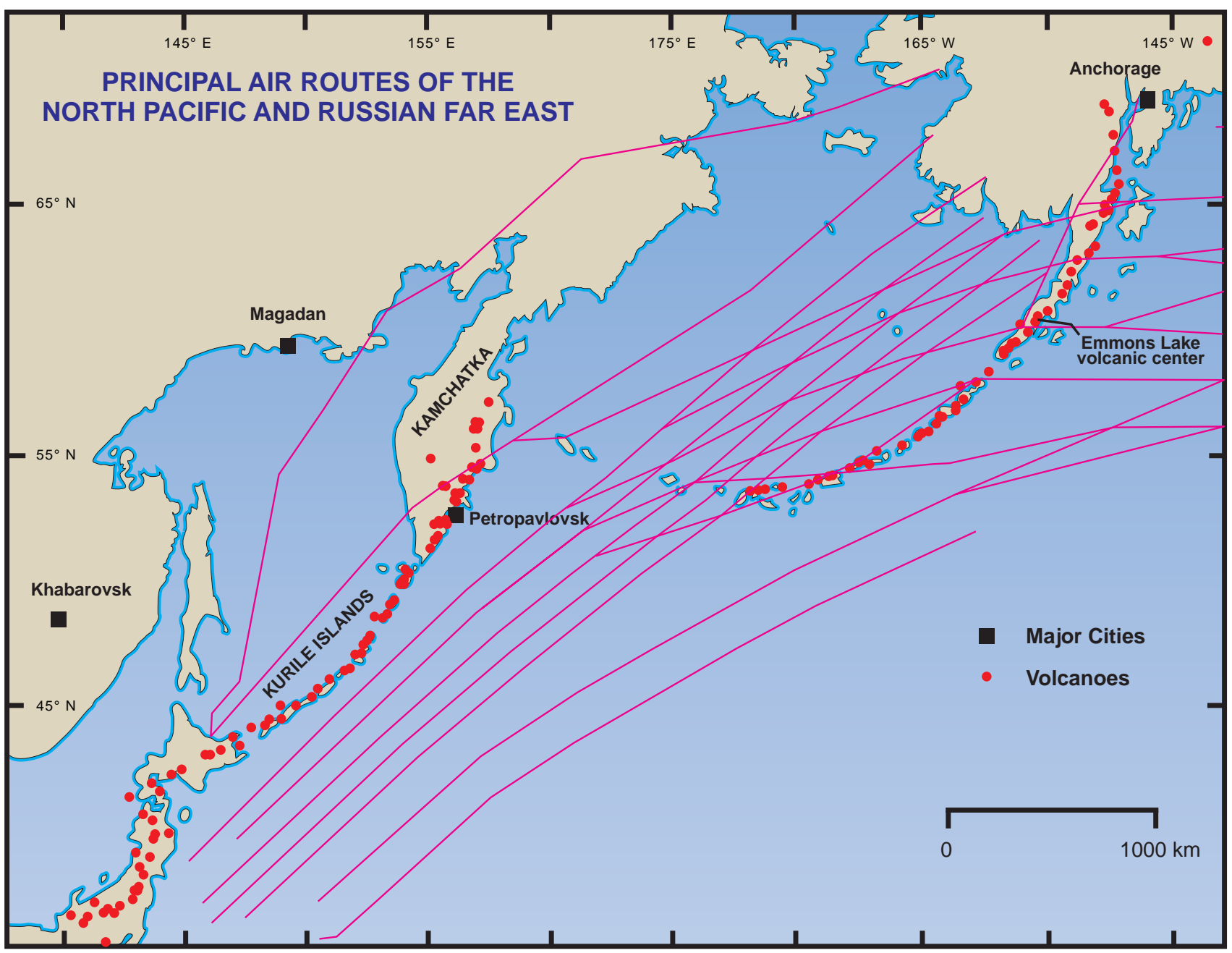

Figure 25. Map showing principal air routes over the North Pacific Ocean relative to the Emmons Lake volcanic center and other volcanoes in Alaska, Russia, the Kurile Islands, and Japan.

occurs, except that it is likely to be similar to those generated by historical eruptions.

\section{Hazard Warning and Mitigation}

Significant eruptions at most volcanoes are typically preceded by weeks to months of precursory earthquake activity, which gives some degree of warning of an impending eruption. Many eruptions also are preceded by at least several weeks of increased steaming and gas emission from the volcano summit. During unrest, volcanoes exhibit a wide range in precursory styles and durations, and periods of unrest may not culminate in an eruption. Fluctuating levels of unrest may occur before or after an individual eruptive episode, or before it becomes clear that an eruption will not occur. Volcanoes may operate on vastly different time scales. Some volcanoes can progress to eruption rapidly (days to weeks), whereas others can take months to years before they erupt. Individual eruptions also can vary in style, from relatively mild effusive events that only produce small lava flows, to extremely explosive events that produce large volumes of ash and pyroclastic material. The duration of a single eruptive episode usually ranges from a few minutes to tens of hours, whereas an entire eruption can last for a day to many decades.

When volcanic unrest is detected, specific monitoring techniques are used to develop a comprehensive assessment of the likelihood of an eruption and its potential hazards. Monitoring techniques can include measurement of volcanicgas flux, remote observation using satellite imagery, direct observation using real-time internet or time-lapse cameras, and geodetic measurements. The Alaska Volcano Observatory (AVO) monitors volcanic unrest at the Emmons Lake volcanic center with a real-time seismic network. A network of eight radio-telemetered seismometers sends real-time radio signals to the AVO offices in Anchorage and Fairbanks. Seismic data and satellite images of volcanoes in the center are analyzed twice daily.

One of the primary roles of the AVO is to communicate timely warnings of volcanic unrest and potential eruptions. 
Table 4. Level of concern color code for hazards to aviation.

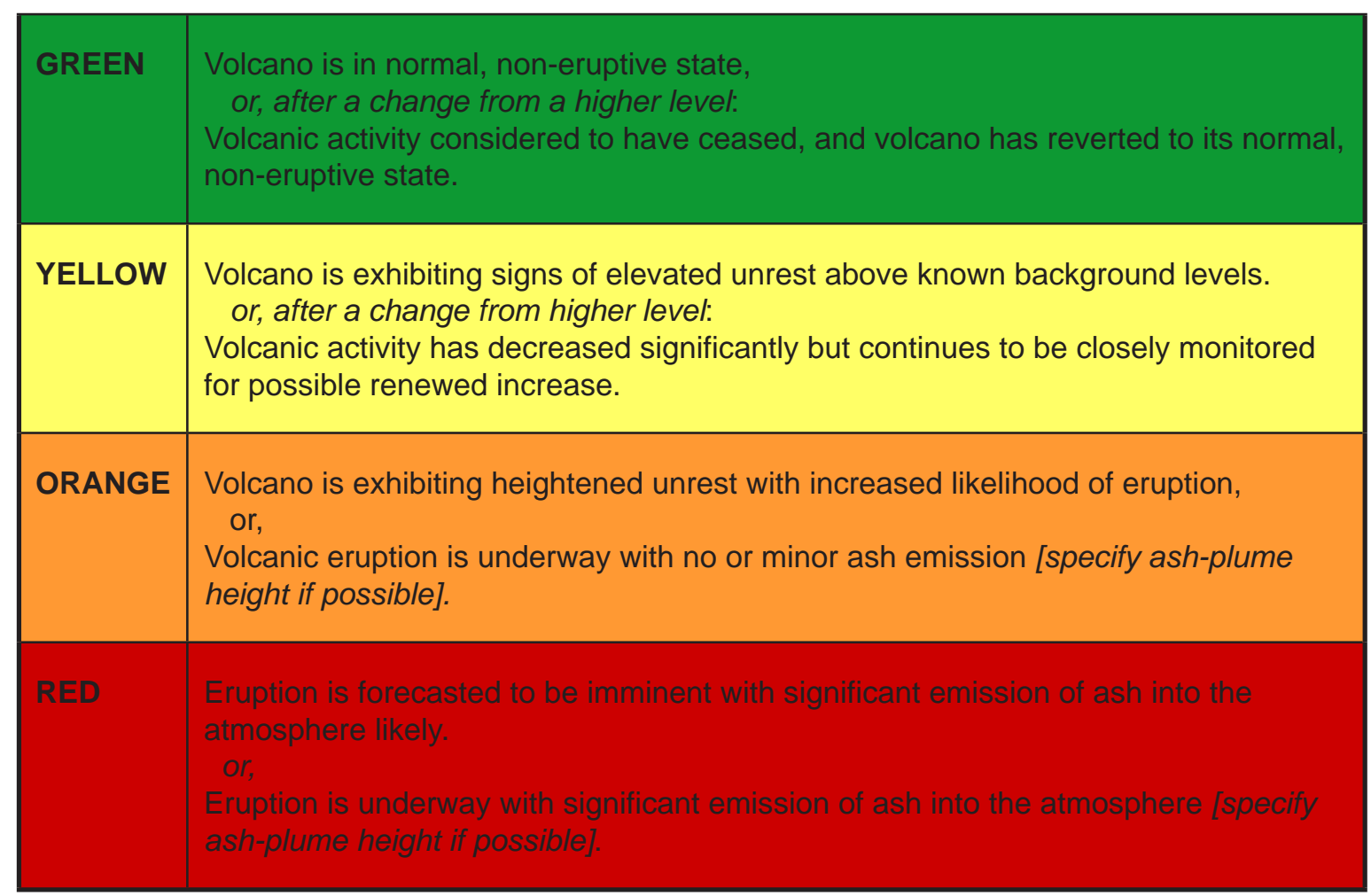

The AVO distributes by fax and electronic mail, daily and weekly statements describing the status of volcanoes showing signs of unrest. During periods of significant unrest or during volcanic crises, information is issued more frequently to advise the public of significant changes in activity. Recipients of this information include government agencies such as the Federal Aviation Administration, the National Weather Service, the Alaska Division of Homeland Security and Emergency Management, local military bases, the Governor's office, and various other State offices. Non-governmental recipients include air carriers, television and radio stations, news wire services, and others. A considerable amount of information about the status and condition of Alaska volcanoes is available on the AVO web site (Www.avo.alaska.edu).

For hazards to aviation, reports of volcanic activity are part of an integrated worldwide warning system that follows procedures sanctioned by the International Civil Aviation Organization (ICAO) and in the United States, that involves the FAA and NOAA. Under ICAO procedures, volcano observatories, including the AVO, notify appropriate officials and representatives of the aviation community about precursory activity and eruptions. A four-part level of concern color code (table 4) focused on ash hazards is used-Green, Yellow, Orange, and Red. The assigned color code is incorporated into the text of a formal notice issued and disseminated by the AVO. Such notices are issued when the activity level at a specific volcano changes (up or down) or when a significant change in volcanic behavior occurs that does not warrant a change in the level of concern color code. All formal infor- mation statements released by the AVO, including volcano advisories, watches, and warnings, will include the "Aviation Color Code" clearly identified as such to differentiate it from other hazard statements.

The level or degree of activity of a volcano is described using the terms "Normal", "Advisory", "Watch", and "Warning" (table 5). These terms signal the conditions of unrest at the volcano and the expected or ongoing hazardous volcanic phenomena. The assignment of an activity level will depend on geological, geophysical, and other monitoring data, and the best available interpretation of the nature of the unrest and its likely outcome. Volcanic-activity notices issued by the AVO are accompanied by explanatory text to give a full description of the observed phenomena and to clarify hazard implications to potentially affected groups. Updates that describe ongoing activity are issued on a regular basis, but may be issued more frequently depending on the nature of the unrest. The activity-level definitions provide guidelines for gauging the level of hazardous activity and for readily disseminating information to public officials and the public to aid in deciding what mitigation actions are necessary. Note that "Watch" is used for both heightened precursory unrest, as well as minor eruptive activity because both situations require attention, but do not have immediate, major hazardous effects. Because the size, style, and reach of eruptions can vary substantially, a higher level ("Warning") is needed to highlight very hazardous eruptive activity.

In most cases, the activity level term and aviation-specific color code will move together ("Normal" and green; 
Table 5. Summary of Volcanic-Activity Alert Levels.

\begin{tabular}{|l|l|}
\hline NORMAL & $\begin{array}{l}\text { Typical background activity of a volcano in a non-eruptive state } \\
\text { After a change from a higher level: } \\
\text { Volcanic activity considered to have ceased, and volcano reverted to its normal, } \\
\text { non-eruptive state. }\end{array}$ \\
\hline ADVISORY & $\begin{array}{l}\text { Elevated unrest above known background activity } \\
\text { After a change from a higher level: } \\
\text { Volcanic activity has decreased significantly but continues to be closely } \\
\text { monitored for possible renewed increase. }\end{array}$ \\
\hline WATCH & $\begin{array}{l}\text { Heightened/escalating unrest with increased potential for eruptive } \\
\text { activity OR a minor eruption underway that poses limited hazards }\end{array}$ \\
\hline WARNING & Highly hazardous eruption underway or imminent \\
\hline
\end{tabular}

"Advisory" and yellow; "Watch" and orange; "Warning" and red). However, there may be occasions when activity at a volcano poses a hazard to aviation that is significantly lower than the ground-based hazard. For example, a large lava flow approaching a town ("Volcano Warning" in effect) is unlikely to produce ash that could enter flight routes or reach a nearby airport (aviation color code yellow or orange).

Minimizing the risks posed by eruptions from the Emmons Lake volcanic center is possible through understanding potential hazards, adequate warning of eruptive activity, and preparing for an eruption. Areas within about 10 to 20 kilometers of the Emmons Lake volcanic center are at some risk from all hazardous volcanic phenomena. Knowledge of potential hazards is important to be able to adequately assess the risk associated with a specific location on or near the volcano and to assess whether or not movement to another location would be safer. Those who visit the area should recognize that terrain within about 20 kilometers of Pavlof Volcano, as well as all areas downwind from the vent, are subject to tephra and ballistic fallout during eruptions. Low-lying terrain along streams and gullies that extend toward the summit of Pavlof is subject to pyroclastic flows and surges, lahars, lahar-runout flows, floods, and avalanches. It is not known if the present configuration of the Pavlof vent, on the north side of the summit, will remain the same during a future eruption. Thus, it is possible that other flanks of the volcano could be swept by pyroclastic flows and receive tephra fallout. During an eruption, access closer than about 10 kilometers from the volcano could be impossible and the risks to human life great.

Small planes and helicopters seeking a view of an eruption could be at risk from intermittent and unpredictable discharge of ballistic projectiles (volcanic bombs) or sudden changes in the travel direction of the eruption plume. People and facilities located farther away from the volcano may have additional time to prepare for the adverse effects of an erup- tion. However, an emergency plan developed and ready prior to the onset of an eruption is useful. Planning for volcanic emergencies is similar to planning for other emergencies, such as flooding, earthquakes, or extreme weather. The sources of emergency information are often the same and the usual interruption of essential services may result. Thus, planning for interruptions in electrical service, transportation (especially air travel), and outdoor activities is appropriate for volcanic emergencies. 


\section{References Cited}

Becker, G.F., 1898, Reconnaissance of the gold fields of southern Alaska with some notes on general geology: U.S. Geological Survey Annual Report 18, p. 1-86, 6 sheets, scale unknown.

Coats, R.R., 1950, Volcanic activity in the Aleutian Arc: U.S. Geological Survey Bulletin B 974-B, p. 35-49, 1 sheet, scale unknown.

Coats, R.R., 1964, Aleutian Islands and Alaska: Bulletin of Volcanic Eruptions, v. 4, p. 4.

Dall, W.H., 1870, Alaska and its resources: Boston, Lee and Shepard, $627 \mathrm{p}$.

Decker, R.W., 1967, Investigations at active volcanoes: Eos, Transactions of the American Geophysical Union, v. 48, p. 639-647.

Doroshin, P., 1870, Some volcanoes, their eruptions, and earthquakes in the former Russian holdings in America (translated in 1982 by J.B. Kisslinger): Verhandlungen der Russisch-kaserlichen mineralogischen Gesellschaft, v. 2 seriia, p. 25-44.

Finch, R.H., 1931, Notes from the Aleutian Islands: The Volcano Letter, v. 357, p. 2-3.

Grewingk, Constantine, 1850, Grewingk's geology of Alaska and the Northwest Coast of America [edited by Marvin W. Falk, translation by Fritz Jaensch published 2003]: Fairbanks, AK, The University of Alaska Press, Rasmuson Library Historical Translation Series 11, 242 p.

Hantke, Gustav, 1951, Uebersicht ueber die vulkanische Taetigkeit 1941-1947: Bulletin Volcanologique, v. 11, p. $161-208$

Hantke, Gustav, 1955, Uebersicht ueber die vulkanische Taetigkeit 1948-1950: Bulletin Volcanlogique, v. 14, p. 151184.

Hoblitt, R.P., Walder, J.S., Dreidger, C.L., Scott, K.M., Pringle, P.T., and Vallance, J.W., 1995, Volcano hazards from Mount Rainier, Washington: U.S. Geological Survey OpenFile Report 98-273, 12 p.

Jacob, K.H., and Hauksson, Egill, 1983, A seismotectonic analysis of the seismic and volcanic hazards in the Pribilof Islands-Eastern Aleutian Islands Region of the Bering Sea: Lamont-Doherty Geological Observatory of Columbia University Annual Report NOAA 03-5-022-70, 224 p.

Jaggar, T.A., 1929, Aleutian notes: The Volcano Letter, v. 246, p. 1.
Jones, A.E., 1952, Aleutian volcanoes: The Volcano Letter, v. 516, p. 8-9.

Kennedy, G.C., and Waldron, H.H., 1955, Geology of Pavlof Volcano and vicinity Alaska: U.S. Geological Survey Bulletin 1028-A, 19 p.

Mangan, M.T., Waythomas, C.F., Miller, T.P., and Trusdell, F.A., 2003, Emmons Lake Volcanic Center, Alaska Peninsula: Source of the Late Wisconsin Dawson tephra, Yukon Territory, Canada: Canadian Journal of Earth Sciences, v. 40 , no. 7 , p. $925-936$.

McGimsey, Robert G., Neal, Christina A., and Girina, Olga, 2005, 2003 volcanic activity in Alaska and Kamchatka: Summary of events and response of the Alaska Volcano Observatory: U.S. Geological Survey Open-File Report 2005-1310, 62 p.

McNutt, S., and Shackelford, D. C., 1983, Pavlof; 쓰 Annual report of the world volcanic eruptions in 1981: Bulletin of Volcanic Eruptions, v. 21, p. 60-61.

McNutt, S.R., 1987, Eruption characteristics and cycles at Pavlof Volcano, Alaska, and their relation to regional earthquake activity: Journal of Volcanology and Geothermal Research, v. 31, nos. 3-4, p. 239-267.

Miller, T., and McNutt, S., 1986, Pavlof: in Annual report of the world volcanic eruptions in 1983, Bulletin of Volcanic Eruptions, v. 23, p. 38.

Miller, T.P., McGimsey, R.G., Richter, D.H., Riehle, J.R., Nye, C.J., Yount, M.E., and Dumoulin, J.A., 1998, Catalog of the historically active volcanoes of Alaska: U.S. Geological Survey Open-File Report 98-582, 104 p.

Miller, T.P., and Casadevall, T.J., 2000, Volcanic ash hazards to aviation; in, Sigurdsson, H., ed., Encyclopedia of Volcanoes: San Diego, Academic Press, p. X-X.

Neal, C.A., McGimsey, R.G., 1997, 1996 volcanic activity in Alaska and Kamchatka; summary of events and response of the Alaska Volcano Observatory: U.S. Geological Survey Open-File Report 97-433.

Neal, C.A., McGimsey, R.G., and Chubarova, Olga, 2004, 2000 volcanic activity in Alaska and Kamchatka; Summary of events and response of the Alaska Volcano Observatory: U.S. Geological Survey Open-File Report 2004-1034, 37 p.

Powers, H.A., 1953, Current activity of Aleutian volcanoes: The Volcano Letter, v. 522, p. 6.

Reeder, J.W., 1990, Pavlof; in Annual report of the world volcanic eruptions in 1987: Bulletin of Volcanic Eruptions, v. 27 , p. $52-56,74-79$.

Sapper, Karl, 1917, Katalog der geschichtlichen vulkanausbruche: Strassburg, Germany, Karl J. Trubner, 358 p. 
Shackelford, D.C., 1977, Pavlof; in Annual report of the world volcanic eruptions in 1975 with supplements to the previous issues: Bulletin of Volcanic Eruptions, v. 15, p. 41.

Shackelford, D.C., 1982, Pavlof; in Annual report of the world volcanic eruptions in 1980: Bulletin of Volcanic Eruptions, v. 20 , p. 70 .

Siebert, L., 1996, Hazards of large volcanic debris avalanches and associated eruptive phenomena; in Scarpa, R., and Tilling, R.I., eds., Monitoring and mitigation of volcano hazards: Berlin, Springer-Verlag, p. 541-572.

Stone, D.B., and Kienle, J., 1975, Pavlov; in Annual report of the world volcanic eruptions in 1973 with supplements to the previous issues: Bulletin of Volcanic Eruptions, v. 13, p. 50.

Vallance, J.W., 1999, Postglacial lahars and potential hazards in the White Salmon River system on the southwest flank of Mount Adams, Washington: U.S. Geological Survey Bulletin 2161, 49 p.

Vallance, J.W., and Scott, K.M., 1997, The Osceola mudflow from Mount Rainier-Sedimentology and hazard implications of a huge clay-rich debris flow: Geological Society of America Bulletin, v. 109, p. 143-163.

Yount, M. E., Taber, J. J., Reeder, J. W., and Miller, T., 1989, Pavlof; in Annual report of the world volcanic eruptions in 1986: Bulletin of Volcanic Eruptions, v. 26, p. 54-57.

\section{Glossary}

Agglutinate. A welded pyroclastic deposit composed of volcanic bombs fused together while hot and somewhat viscous.

Andesite. A fine-grained volcanic rock made up of feldspars and ferromagnesian minerals; by definition has a silica content of 54 to about 62 percent.

Angle of repose. The maximum slope, measured in degrees from the horizontal, at which loose solid material will remain in place without sliding.

Ash. Fine fragments (less than $2 \mathrm{~mm}$ across) of volcanic rock formed in an explosive volcanic eruption. Ash particles are typically sharp, angular, and abrasive, and are composed of volcanic glass, mineral, and rock fragments.

Debris avalanche. Rapidly moving, dry flows of dissaggregated rock debris, sand, and silt. Volcanic debris avalanches often form by some type of structural collapse of the volcano, usually the steep front of the cooled lava dome, or other parts of the upper edifice. A large portion of the volcano may become unstable, break away from the volcanic massif, and become an avalanche. A debris avalanche may be triggered by an eruption or earthquake. Debris avalanches move at velocities ranging from a few tens of ms per second to more than $100 \mathrm{~ms}$ per second and behave like complex granular flows or slide flows. Often they are quite voluminous (greater than 10 cubic kilometers) and may run out considerable distances (up to 85 kilometers) from their source. The resulting debris-avalanche deposit usually exhibits hummocky surface morphology.

Directed blast. Large-scale volcanic explosions caused by a major landslide or slope failure that results in a rapid drop in the pressure of the intruding magma or hydrothermal system near the surface of the volcanic edifice. The 1980 eruption of Mount St. Helens was triggered by a massive slope failure and the subsequent laterally directed blast affected a $180^{\circ}$ sector north of the volcano and extended for several tens of kilometers outward. A directed blast typically travels away from the volcano at a low angle and may not be deflected by ridges or other topographic barriers. Rock debris propelled by a directed blast moves much faster than typical landslides and rockfalls. For example, at Mount St. Helens, the initial velocity of the directed blast cloud was about 600 kilometers 
per hour decreasing to about 100 kilometers per hour at a distance 25 kilometers from the volcano.

Edifice. The upper part of the volcanic cone, including the vent and summit areas.

Effusive. A nonexplosive eruption characterized by the production of lava flows.

Eruption cloud. Cloud of gas, ash, and other fragments that forms during an explosive volcanic eruption and travels long distances with the prevailing winds.

Eruption column. The vertical portion of the eruption cloud that rises above a volcanic vent.

Fallout. A general term for debris that falls to the earth from an eruption cloud.

Holocene. The Holocene epoch is a geological period that extends from the present day to back about 10,000 radiocarbon years, approximately $11,430 \pm 130$ calendar years BP (between 9560 and 9300 BC). Its name comes from the Greek words "holo" which means whole or entire and "cene" which means new or recent.

Lahar. An Indonesian term for a wet debris flow containing angular clasts of volcanic material. For the purposes of this report, a lahar is any type of sediment/water mixture originating on or from the volcano. Most lahars move rapidly down the slopes of a volcano as channelized flows and deliver large amounts of sediment to the rivers and streams that drain the volcano. The flow velocity of some lahars may be as high as 20 to $40 \mathrm{~ms}$ per second (Blong, 1984) and sediment concentrations of $>750,000$ parts per million are not uncommon. Large volume lahars can travel great distances if they have an appreciable clay content (> 3 to 5 percent), remain confined to a stream channel, and do not significantly gain sediment while losing water. Thus, they may affect areas many tens to hundreds of kilometers downstream from a volcano.

Lapilli. Ejected rock or pumice fragments between 2 and $64 \mathrm{~mm}$ in diameter.

Lava. Molten rock that reaches the earth's surface.

Magma. Molten rock beneath the Earth's surface.
Monogenetic. A volcano or volcanic vent built up by a single eruption.

Pleistocene Epoch. The period of Earth history between 1.8 million and 10 thousand years before present.

Pumice. Highly vesicular, silica-rich volcanic ejecta; due to its extremely low density, it often floats on water.

Pyroclastic. General term applied to volcanic products or processes that involve explosive ejection and fragmentation of erupting material.

Pyroclastic flow. A dense, hot, chaotic avalanche of rock fragments, gas, and ash that travels rapidly away from an explosive eruption column, often down the flanks of the volcano (synonymous with "ash flow"). Pyroclastic flows move at speeds ranging from 10 to several hundred ms per second and are typically at temperatures between 300 and $800^{\circ} \mathrm{C}$. Pyroclastic flows form either by collapse of the eruption column, or by failure of the front of a cooling lava dome. Once these flows are initiated, they may travel distances of several kilometers or more and easily override topographic obstacles in the flow path. A person could not outrun an advancing pyroclastic flow.

Pyroclastic surge. A low-density, turbulent flow of finegrained volcanic rock debris and hot gas. Pyroclastic surges differ from pyroclastic flows in that they are less dense and tend to travel as a low, ground-hugging, but highly mobile cloud that can surmount topographic barriers. Surges often affect areas beyond the limits of pyroclastic flows.

Spatter. An accumulation of initially fluid pyroclasts that develop and build up around the vent of an erupting volcanic cone.

Stratovolcano. (also called a stratocone or composite cone) A steep-sided volcano, usually conical in shape, built of lava flows and fragmental deposits from explosive eruptions.

Strombolian. Strombolian eruptions are relatively low-level volcanic eruptions, named after the Italian volcano named Stromboli, where such eruptions consist of rhythmical ejection of incandescent cinder, lapilli and lava bombs to altitudes of tens to hundreds of meters. They are small to medium in volume, with sporadic violence. The tephra typically glows red when leaving the vent, but its surface cools and assumes a dark to black color and nearly solidifies before impact. The 
tephra accumulates in the vicinity of the vent, forming a cinder cone. Cinder is the most common product, the amount of volcanic ash is typically rather minor.

Tephra. Tephra is any type of rock fragment that is forcibly ejected from the volcano during an eruption. Tephra may be fine-grained dust or "ash" (0.0625 to $2 \mathrm{~mm}$ diam-silt to sand sized), coarser "lapilli" ( 2 to $64 \mathrm{~mm}$ diam—sand to pebble sized), or consist of large blocks or bombs (>64 mm-cobble to boulder sized). When tephra is airborne, the coarsest fraction will be deposited close to the volcano, but the fine fraction may be transported long distances and can stay suspended in the atmosphere for many months.

Vent. An opening in the Earth's surface through which magma erupts or volcanic gasses are emitted. 